\title{
Reregulating the Baby Market: A Call for a Ban on Payment of Birth-Mother Living Expenses
}

\author{
Andrea B. Carroll
}

\section{INTRODUCTION}

About the laudability of a general scheme of domestic adoption, few would disagree. Adoption provides a means of building families, hope for children in need, and a stabilizing influence for a society searching for aid in caring for its most helpless citizens. Still, one need not look far to find that the domestic adoption system in the United States is broken. ${ }^{1}$ Evidence pointing toward such a conclusion abounds. About half a million children find themselves in the American foster care system on any given day, many with little chance of being either reunified with their birth families or placed in a permanent adoptive home. ${ }^{2}$ Even outside the sphere of state-run care, this country's domestic adoption scheme fails many of the players involved. Adoptive parents, in particular, often become victims of the flawed scheme of private and agency adoption. ${ }^{3}$ And though it may seem at first blush as though

* C.E. Laborde, Jr. Professor of Law, Louisiana State University, Paul M. Hebert Law Center I thank Lucy McGough, Shaun Shaughnessy, and the participants at the 2009 Washington and Lee University School of Law Children and the Law Workshop for the opportunity to present and receive valuable feedback on an earlier draft of this piece. I am also grateful to the LSU Law Center for its generous research support. Casey Faucon and Irina Fox (LSU Law Center Class of 2010) provided excellent research assistance.

1. See Erika Lynn Kleiman, Caring for Our Own: Why American Adoption Law and Policy Must Change, 30 Colum. J.L. \& Soc. ProBS. 327, 327-28 (1997) (arguing that "certain American laws and policies force many prospective adoptive parents to look outside the United States to find children"); Lynn D. Wardle, Parentlessness: Adoption Problems, Paradigms, Policies, and Parameters, 4 WhitTiER J. ChiLD. \& FAM. Advoc. 323, 332-36, 352 (2005) ("Legal impediments directly and significantly restrict and limit the incidence of adoption."); Candace M. Zierdt, Compensation for Birth Mothers: A Challenge to the Adoption Laws, 23 LoY. U. CHI. L.J. 25, 26 (1991) (explaining how the current adoption scheme has resulted in a "black market" that takes advantage of adoptive parents, birth parents, and children).

2. See Joan R. Rycraft, How to Improve the Likelihood of Successful Family Reunification, in

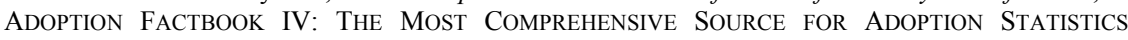
NATIONWIDE 351, 351-52 (Thomas C. Atwood et al. eds., 2007).

3. Sale of Children in Interstate and Foreign Commerce: Hearings Before the Subcomm. on Criminal Justice of the H. Comm. on the Judiciary, 95th Cong. 4 (1977) [hereinafter Hearings] (statement of Hon. Robert K. Dornan, Rep. of Cal.); see also 1 ThOmas A. JaCOBS, CHILDREN \& 
adoptive parents are the members of the adoption triad ${ }^{4}$ least deserving of sympathy, the result of a legal scheme that disfavors adoptive parents so substantially is quite troubling. In 2009 alone, nearly 13,000 children were adopted from countries outside the United States. ${ }^{5}$ And while there is every reason to believe that wonderful families were created in these matches, the choice of so many American families to avoid domestic adoption is a significant one because it tends to negatively impact the fate of American children in need of adoption.

Even a glance at state law on infant adoption quickly illuminates the rationale of adoptive parents' decisions to adopt internationally. Planned domestic adoptions of newborns fail ${ }^{6}$ at an alarming rate. ${ }^{7}$ Perhaps more importantly, when such failures occur, adoptive parents find themselves out more than just emotion. Significant money is nearly always at stake as well. ${ }^{8}$

In 1978, renowned law and economics scholar and future jurist Richard Posner published an article in which he described child adoption as a market activity - essentially a sale or trade "realized by a process of voluntary transacting." " He went on to catalogue the substantial disparity

THE LAW: RighTS \& OBLIGATIONS $§ 4.25$ (1995) (stating that an adoptive family generally assumes the financial risks in a domestic adoption); John R. Maley, Note, Wrongful Adoption: Monetary Damages as a Superior Remedy to Annulment for Adoptive Parents Victimized by Adoption Fraud, 20 IND. L. REV. 709, 711 (1987) ("Instances of adoptive parents being fraudulently induced into an adoption are not new in the United States.").

4. See Zierdt, supra note 1, at 26 (describing adoptive parents, birth parents, and the children to be adopted as the three interested members of the adoption triad).

5. Total Adoptions to the United States, InTERCOUnTRY ADOPTION: OfFICE OF CHILDREN's ISSUES, U.S. DEP'T OF STATE, http://adoption.state.gov/news/total_chart.html (last visited Oct. 7, 2010).

6. As I intend the phrase here, the failure of a planned adoption includes both a decision by birth parents not to place the child with adoptive parents as previously planned and removal of the child from the adoptive home after placement but before the adoption is finalized.

7. See Dan Gearino, Money, Hope Lost in Failed Adoptions, QuAD-City Times (Feb. 21, 2006, 12:00 AM), http://www.qctimes.com/news/local/article_4fd32e38-7947-5759-9d40-8c6f2948 e2cc.html (describing a survey conducted by Adoptive Families magazine that found that twentynine percent of readers polled had a failed domestic adoption); Susan Scherreik, Adoption: Now There's the Cyber-Stork, Bus. WK., Aug. 14, 2000, at 134E2, 134E4 (estimating a failure rate of between twenty-five and fifty percent). But see Alfred Kadushin \& Frederick W. Seidl, Adoption Failure: A Social Work Postmortem, 16 SOC. WORK 32, 34 (1971) (arguing that the agency adoption failure rate is extremely low); Katharine Q. Seelye, Specialists Report Rise in Adoptions that Fail, N.Y. TimES, Mar. 24, 1998, at A14 (stating that domestic adoptions fail at a rate of 4.7 to 10 percent but the rates are increasing).

8. The total cost of a domestic adoption can be more than $\$ 40,000$, depending on the circumstances and the state of adoption. ChILD Welfare INFO. GATEWAY, COSTS OF ADOPTING 2 (2004) [hereinafter COSTS OF ADOPTING], available at http://www.childwelfare.gov/pubs/s_cost/ s_costs.pdf.

9. Elisabeth M. Landes \& Richard A. Posner, The Economics of the Baby Shortage, 7 J. LEGAL STUD. 323, 324 (1978). 
between supply and demand in the adoption context largely created by government prevention of the operation of a legal market for babies. ${ }^{10}$ Posner opined that this model of adoption regulation has led to a black market for babies and suggested that an experimental move toward a free market in adoption may yield evidence on whether the experiment would solve the supply and demand mismatch plaguing the system. $^{11}$ Specifically, Posner suggested that adoption agencies take a fee surplus that could be generated by charging wealthy couples comparatively more for the agencies' services and using those profits to pay pregnant women considering terminating their pregnancies through abortion to incentivize them to instead carry the baby to term and relinquish it for adoption. ${ }^{12}$ The value of the experiment, Posner suggested, would be the creation of data that could help to remedy the supply and demand disparity, including figures on what adoptive parents would be willing to pay for a child and just how much money pregnant women would require to carry a baby to term and subsequently execute a surrender of parental rights. ${ }^{13}$

Posner's article was exceptionally controversial, ${ }^{14}$ so much so that pundits speculated it may be one of the most significant reasons he could never be successfully nominated to serve as a justice of the United States Supreme Court. ${ }^{15}$ Posner himself felt compelled to defend the article twenty-five years later, noting that he never "advocated "baby selling," but rather argued that state law in the 1970s, which capped the sums that could be paid in connection with child adoption at a nominal amount, might be modified experimentally to determine whether it would increase the baby supply. ${ }^{16}$

Thirty years later, Posner has come startlingly close to getting his wish. Baby selling is still uniformly illegal in the United States, ${ }^{17}$ but our

10. See id. at $324-25$.

11. Id. at $324,347-48$.

12. Id. at $347-48$.

13. Id. at 348 .

14. See Ronald A. Cass, Coping with Life, Law, and Markets: A Comment on Posner and the Law-and-Economics Debate, 67 B.U. L. REV. 73, 73 (1987); Jane Maslow Cohen, Posnerism, Pluralism, Pessimism, 67 B.U. L. REV. 105, 105 (1987).

15. Robert S. Boynton, Sounding Off, WASH. Post, Jan. 20, 2002, at T8.

16. Howard Bashman, 20 Questions for Circuit Judge Richard A. Posner of the U.S. Court of Appeals for the Seventh Circuit, How APPEALING (Dec. 1, 2003, 12:00 AM), http://howappealing. law.com/20q/2003_12_01_20q-appellateblog_archive.html\#107025481874565902.

17. See Ariz. Rev. Stat. AnN. § 8-114(C) (2007); Colo. Rev. Stat. AnN. § 19-5-213(1)(a) (West 2005 \& Supp. 2009); Del. Code ANN. tit. 13, § 928(a) (West 2006); IOWA CodE ANN. $\S 600.9(1)$ (West 2001 \& Supp. 2010); KAN. STAT. ANN. § 59-2121(a) (2005); Ky. ReV. STAT. ANN. $\S 199.590(2)$ (West 2006); LA. REV. STAT. ANN. § 14:286(A) (2004); Mich. CoMP. LAWS ANN. $\S 710.54$ (West 2002); Miss. Code ANN. § 43-15-23 (West 2008); Nev. Rev. STAT. AnN. 
system of domestic infant adoption is an exceptionally expensive transaction which comes rather close. ${ }^{18} \mathrm{~A}$ domestic adoption can frequently cost roughly $\$ 40,000$, a substantial sum even when one considers the fees of the agents and lawyers involved. ${ }^{19}$ One of the most significant of the expenses surrounding the domestic adoption of a newborn comes not from any of these professional fees, ${ }^{20}$ however, but rather from the payment of living expenses to the expectant mother. ${ }^{21}$ Adoptive parents typically front these monies under the sanction of state law authorizing such expenditures. ${ }^{22}$

This scheme, under which substantial living expenses are paid to a prospective birth mother, ${ }^{23}$ who makes the ultimate choice to parent her child the vast majority of the time, ${ }^{24}$ is fraught with problems. Comparisons between baby selling and a scheme allowing for the payment of substantial sums for housing or other expenses of daily life

$\S 127.287$ (1) (West 2008); N.H. ReV. STAT. ANN. § 170-B:13(II) (Supp. 2009); N.Y. Soc. SERV. LAW § 374(6) (McKinney 2003 \& Supp. 2010); N.C. GEN. STAT. ANN. § 48-10-102(a) (West 2000); OHIo Rev. Code ANN. § 3107.055(C) (West Supp. 2009); OR. ReV. Stat. AnN. § 109.311(3) (West 2003 \& Supp. 2010); S.C. CodE ANN. § 63-9-310(F) (2010); VT. STAT. ANN. tit. 15A, § 7-105 (West 2007); VA. CODE ANN. § 63.2-1218 (West 2002); WASH. REV. CODE ANN. § 9A.64.030(1) (West 2009); see also William MeEZAn Et AL., Adoptions Without Agencies: A Study of INDEPENDENT ADOPTIONS 182-98 (1978); Vanessa S. Browne-Barbour, Bartering for Babies: Are Preconception Agreements in the Best Interests of Children?, 26 WHITTIER L. REV. 429, 473 (2004) (arguing that preconception agreements also constitute baby selling and are void and unenforceable).

18. See Richard A. Posner, The Regulation of the Market in Adoptions, 67 B.U. L. REV. 59, 71 (1987) (arguing that the legal scheme allowing the payment of substantial sums to birth mothers is really a sale in disguise). But see Zierdt, supra note 1, at 44 (stating that compensating birth mothers is not baby selling).

19. Costs OF AdOPTING, supra note 8, at 2. Some complicated domestic adoptions cost upwards of $\$ 100,000$. See Laura Mansnerus, Market Puts Price Tags on the Priceless, N.Y. TIMES, Oct. 26, 1998, at A1.

20. Legal expenses in an adoption may include attorneys' fees for the birth parents, adoptive parents, a guardian for the child, and an adoption agency. 1 JACOBS, supra note $3, \S 4: 26$.

21. See Melinda Lucas, Essay, Adoption: Distinguishing Between Gray Market and Black Market Activities, 34 FAM. L.Q. 553, 556 (2000). See generally Gearino, supra note 7 (adoptive mother estimates that she and her husband spent about $\$ 25,000$ on the adoption, which included several months of living expenses); Ryan Mills, Woman Fakes Pregnancy in Adoption Scam, SCRIPPSNEWS (Aug. 1, 2008), http://www.scrippsnews.com/node/35187/12187 (adoptive father said he and his wife "paid close to $\$ 4,000 \ldots$ in living expenses").

22. See, e.g., Fla. Stat. AnN. § 63.212(1)(h) (West 2005 \& Supp. 2010); TENn. Code AnN. $\S 36-1-109$ (a)(1)(B)(i) (West 2005); UtAH CODE ANN. § 76-7-203 (West 2004 \& Supp. 2010).

23. Some have argued against the use of terms such as "birth family," "birth parent," and "birth mother," arguing that they are imbued with negative connotations. See John Lawrence Hill, What Does It Mean to Be a "Parent"? The Claims of Biology as the Basis for Parental Rights, 66 N.Y.U. L. REV. 353, 358-66 (1991). Nonetheless, I use these terms to describe the biological parents of the adopted child as the phrases are still the most well-recognized and accepted labels for these groups.

24. It is estimated that as many as eighty percent of pregnant women who work with adoption agencies and attorneys to select a placement for their unborn child decide to parent the child instead of going through with the adoptive placement. Mansnerus, supra note 19, at A17. 
are almost inescapable. ${ }^{25}$ Questions about the voluntariness of a birth mother's surrender arise in connection with the payment of living expenses and are weightier than the concerns surrounding other types of adoption-related expenses. ${ }^{26}$ Moreover, birth mothers often actually profit from the payment of their living expenses, necessarily raising the same concerns which have been used to justify a ban on baby selling. ${ }^{27}$ Perhaps worst is that because not all birth mothers are similarly valued, allowing prospective adoptive parents to pay birth-mother living expenses serves to injure society as a whole by striating race and class divisions.

Part II of this Article describes the varying approaches states have taken for regulation of housing payments and similar expenses in connection with child adoption. This Part explores state laws allowing virtually unfettered payment of actual living expenses and state bans on all such payments, along with solutions on the continuum between these two. Part III details the harms of existing state rules sanctioning the payment of birth-mother living expenses by prospective adoptive parents, including a discussion of the slippery slope that separates the payment of expenses from baby selling, the potential for serious questions regarding the voluntariness of the birth mother's surrender of

25. "Baby selling" is generally statutorily defined as the giving or receiving of anything of value in exchange for the consent to or placement of a child for adoption. See, e.g., CAL. PEnAL CODE $§ 273$ (a) (West 2008) ("It is a misdemeanor for any person or agency to pay, offer to pay, or to receive money or anything of value for the placement for adoption or for the consent to an adoption of a child."). Certainly, housing payments would be construed as a "thing of value."

26. Cf. Katy Ruth Klinke, Note, The Baby M Controversy: A Class Distinction, 18 OKLA. CITY U. L. REV. 113, 118-19 (1993) ("[M]others who receive compensation for their consent to allow adoption are often pressured into not changing their minds."). See generally Jonathan M. Purver, Undue Influence in Obtaining Parent's Consent to Adoption of Child, 8 AM. JUR. PROOF OF FACTS 2d 481 (1976 \& Supp. 2002) (describing public policies implicated by the use of coercion in obtaining consent to relinquish a child).

27. Baby selling is against public policy because it preys on a financially subordinate birth mother, providing monetary incentive to relinquish her parenting rights. See Matthew H. Baughman, In Search of Common Ground: One Pragmatist Perspective on the Debate over Contract Surrogacy, 10 COLUM. J. GENDER \& L. 263, 271 (2001) ("[W]e fear that when poor people try to sell their organs, or poor women sell their bodies for sex, they may be engaging in the transaction out of brute necessity, and not because they have made a rational choice from a position of equal bargaining power."); Daniel J.H. Greenwood, Beyond the Counter-Majoritarian Difficulty: Judicial DecisionMaking in a Polynomic World, 53 RUTGERS L. REV. 781, 820 (2001) ("Baby-selling ... [is] not permitted in decent market societies, perhaps because it seems hard to believe that any normal person would sell their baby ... except under duress, that is, when faced with a set of choices that no one should have to face."). Allowing the payment of birth-mother living expenses raises the same concerns; the payments incentivize a birth mother to relinquish her parental rights in exchange for a more comfortable standard of living. See Joan Heifetz Hollinger, Adoption Law, 3 FUTURE OF CHILD.: AdOPTION, Spring 1993, at 43, 44, 49 (characterizing adoption as a donative transaction which is not supposed to generate financial gain). 
her child, the likely discouragement of prospective adoptive parents from pursuing domestic adoption, and the misplacement of the burden of supporting society's most needy citizens. Part IV concludes by calling for a change from prevalent models of regulation to an outright ban on the payment of living expenses. Such a change is important, even necessary, because it is not merely the financial fate of adoptive parents at stake. Rather, improvement of our domestic adoption scheme could significantly affect the future of American children and, ultimately, the welfare of our society.

\section{State LAW Alternatives to REgUlation OF LiVING-EXPENSE PAYMENTS}

At least one thing regarding the financial implications of child adoption is clear. Many American states, along with their international counterparts, ${ }^{28}$ uniformly prohibit, and even criminalize, the practice of baby selling. ${ }^{29}$ Express prohibitions, typically found in the form of criminal statutes, exist in thirty-two states, ${ }^{30}$ and at least thirteen states have jurisprudence decrying the practice. ${ }^{31}$ For more than fifty years,

28. See Convention on Protection of Children and Co-operation in Respect of Intercountry Adoption, May 29, 1993, 32 I.L.M. 1134, available at http:/www.hcch.net/upload/conventions/ txt33en.pdf (articulating an international policy for the protection of children in intercountry adoption)

29. See Browne-Barbour, supra note 17, at 473 ("[S]tate adoption laws uniformly prohibit adoptions for money, that is, baby selling.").

30. See Ala. Code $§ 26-10 A-34$ (2009); Cal. Penal Code $§ 273$ (a) (West 2008); Colo. Rev. StAT. ANN. § 19-5-213 (West 2005 \& Supp. 2009); Fla. StAT. ANN. § 63.212(1)(c) (West $2005 \&$ Supp. 2010); GA. CoDE ANN. § 19-8-24(b) (West 2010); IDAHO CodE ANN. § 18-1511 (West 2006); IND. CODE ANN. § 35-46-1-9(a) (West 2004 \& Supp. 2010); IOWA CoDE ANN. § 600.9(1)(c) (West 2001 \& Supp. 2010); Ky. Rev. Stat. Ann. § 199.493(2) (West 2006); LA. Rev. Stat. AnN. $\S 14: 286$ (2004); MD. CODE ANN., CRIM. LAW § 3-603(a) (West 2002); MASS. GEN. LAWS ANN. ch. 210, § 11(A) (West 2007 \& Supp. 2010); MiCH. COMP. LAWS ANN. § 710.54(1) (West 2002); MinN. Stat. AnN. § 259.55 (West 2007); Miss. CODE ANN. § 43-15-23 (West 2008); Mo. AnN. StAT. $\S 568.175(1)$ (West 1999); Mont. Code AnN. § 42-7-105(3) (2009); Nev. Rev. Stat. AnN. $\S 127.287$ (West 2008); N.J. STAT. ANN. § 9:3-39.1(d) (West 2002 \& Supp. 2010); N.Y. Soc. SERV. LAW § 374(6) (McKinney 2003 \& Supp. 2010); N.C. GEN. STAT. ANN. § 48-10-102 (West 2000); N.D. Cent. Code AnN. § 12.1-31-05 (West 2008); OKLA. Stat. AnN. tit. 21, § 866 (West 2002); 18 Pa. Cons. Stat. AnN. § 4305 (West 1983); S.C. Code AnN. § 16-3-1060 (2003 \& Supp. 2009); S.D. CODIFIED LAWS § 25-6-4.1 (2004); TENN. CODE ANN. § 36-1-109 (West 2009); TEX. PENAL CODE ANN. § 25.08 (West 2003 \& Supp. 2010); UTAH CODE ANN. § 76-7-203 (West 2004 \& Supp. 2010); VA. CODE ANN. § 63.2-1218 (West 2002); WASH. REV. CODE ANN. § 9A.64.030(3) (West 2009); W. VA. Code AnN. § 48-22-803 (West 2002); Wis. StAT. AnN. § 948.24 (West 2005).

31. See People v. Daniel, 241 Cal. Rptr. 3, 5-6 (Ct. App. 1987) (affirming conviction of defendant for "sale of a person" for demanding $\$ 90,000$ in exchange for consent to the adoption of his seventeen-month-old daughter); Douglas v. State, 438 S.E.2d 361, 362 (Ga. 1994) (finding offer of automobile in exchange for the biological mother's consent to adoption violated statute making it 
this country has rather strongly and uniformly disapproved of the practice of baby selling. ${ }^{32}$

Yet it is no secret that money changes hands in child adoption. ${ }^{33}$ In fact, the cost of infant and toddler adoption outside the state-run foster care system is staggering, ${ }^{34}$ with a number of players taking a cut. Lawyers are paid handsomely to serve as baby brokers; agencies facilitate adoptions for handsome sums. ${ }^{35}$ And despite the prohibition on

unlawful to induce parents to part with their children); In re Adoption of Kindgren, 540 N.E.2d 485, 488-89 (Ill. App. Ct. 1989) (noting consent was fraudulently obtained where adoptive parents paid birth mother $\$ 10,000$ to cover medical expenses without being aware of what the expenses were); In re Adoption of Baby Boy M., 18 P.3d 304, 307-08 (Kan. Ct. App. 2001) (finding the trial court erred in ordering the adoptive parents to reimburse Medicaid for payments for birth mother's expenses where no law required them to do so); State v. Roberts, 471 So. 2d 900, 901-02 (La. Ct. App. 1985) (biological mother violated statute by traveling to Texas to relinquish her son for sum of \$3000); State v. Runkles, 605 A.2d 111, 120-21 (Md. 1992) (finding mother persuaded by her boyfriend to relinquish child to boyfriend's father for $\$ 4000$ did not violate statute when mother did not know of payment); Doe v. Kelley, 307 N.W.2d 438, 440-41 (Mich. Ct. App. 1981) (finding that consideration in conjunction with the use of the state's adoption procedures was precluded by statute); Balouch v. State, 938 So. 2d 253, 258 (Miss. 2006) (finding defendant violated statute by offering to relinquish her child for \$5000); State v. Daugherty, 744 S.W.2d 849, 853-54 (Mo. Ct. App. 1988) (affirming defendant guilty of trafficking children for offering to pay $\$ 1000$ for the purposes of adoption of a child); Gray v. Maxwell, 293 N.W.2d 90, 95 (Neb. 1980) (finding as against public policy the relinquishment of a child done in consideration of promise to pay a sum of money in excess of legitimate expenses); In re Adoption of Baby Boy P., 700 N.Y.S.2d 792, 798 (Fam. Ct. 1999) (reducing excessive agency fees and disallowing both attorney fees for services provided to the natural father and car maintenance expenses); In re Adoption of Stephen, 645 N.Y.S.2d 1012, 1015 (Fam. Ct. 1996) (finding living expenses paid to birth mother and rent by adoption agency violated statute when relation to pregnancy was not demonstrated); In re Adoption of Alyssa, L.B., 501 N.Y.S.2d 595, 596 (Sur. Ct. 1986) (limiting expenses to those incidental to birth and pregnancy, not including automobile expenses for birth mother); In re Adoption of P.E.P., 407 S.E.2d 505, 509-10 (N.C. 1991) (finding payment of fees including travel expenses, medical expenses of the parent, six month lease of an apartment, weekly stipend for three months, and attorney fees violated statute); In re Baby Girl D., 517 A.2d 925, 927-28 (Pa. 1986) (allowing adoptive parents to pay only expenses related to care of child); DeJesus v. State, 889 S.W.2d 373, 375 (Tex. App. 1994) (upholding defendant's conviction for sale of a child because more than $\$ 10,000$ in payments were made outside of the confines of the statute); Thacker v. State, 889 S.W.2d 380, 383-84 (Tex. App. 1994) (finding defendant violated statute when she paid a mother a total of $\$ 12,000$ in exchange for her children).

32. See People ex rel. Anonymous v. Anonymous, 195 N.Y.S.2d 1009, 1018 (Sup. Ct. 1959) (holding that a demand of money may constitute abandonment of a child). See generally Hearings, supra note 3 (discussing ways to solve the problem of black markets for baby selling).

33. See Maggie Jackson, Aspiring Adoptive Parents Face Greed, Competition, Exploitation, L.A. TIMES, Apr. 23, 1995, at A1, available at http://articles.latimes.com/1995-04-23/news/mn57734_1_independent-adoption.

34. See Costs OF AdOPTING, supra note 8 , at 2 .

35. State laws generally permit agencies to charge service fees for each adoption they facilitate. See Ala. Code § 26-10-4.1; Del. CODE ANN. tit. 13, § 928(b) (West 2006); D.C. CoDE § 4-1410 (2008); 720 ILl. Comp. StAT. ANN. 525/1 (West 2010); KAN. STAT. ANN. § 59-2121(a) (2005); Ky. Rev. STAT. ANN. § 199.590(2); LA. Child. Code AnN. art. 1200(B) (2004); MD. Code ANN., FAM. LAW § 5-362(b) (West 2006); Mont. Code ANN. § 42-7-101(1); NEV. ReV. STAT. ANN. § 127.275; N.H. Rev. StAT. ANN. § 170-B:13(I) (Supp. 2009); N.J. StAT. ANN. § 9:3-39.1(e); N.M. STAT. ANN. 
baby selling, state laws generally sanction the payment of a rather broad variety of fees in connection with an adoptive placement. ${ }^{36}$

Those approved payments include: agency or lawyer fees for making the match between the prospective adoptive parents and the birth family and otherwise facilitating the adoption $;{ }^{37}$ medical expenses associated with the pregnancy and birth of the child ${ }^{38}$ expenses associated with procuring the required mental health counseling for relinquishing birth mothers; ${ }^{39}$ legal fees for judicial proceedings and the completion of

§ 32A-5-34(B) (West 2003 \& Supp. 2009); N.Y. SOC. SERV. LAW § 374(6); N.C. GEN. STAT. ANN. $\S$ 48-10-103(e); OHIO Rev. Code AnN. § 3107.055(C) (West 2005 \& Supp. 2008); OKLa. Stat. ANN. tit. 10, § 7505-3.2 (West 2009); 23 PA. CONS. STAT. ANN. § 2533(d) (West 2001); S.C. CODE ANN. § 63-9-310(F) (2010); VT. STAT. ANN. tit. 15A, § 7-104 (West 2007); VA. CodE ANN. § 63.21218 ; W. VA. CODE ANN. § 48-22-803. An attorney may be paid additional fees by the adoptive family for services in connection with an adoption. See ArIZ. Rev. Stat. AnN. § 8-114(D) (2007); Colo. Rev. Stat. AnN. § 19-5-213(1)(a); Fla. StAT. AnN. § 63.097(2); LA. Child. Code ANN. art. 1200(B) (West 2004); Miss. CODE ANN. § 43-15-23(4); N.H. REV. STAT. ANN. § 170-B:13(I); N.C. Gen. Stat. ANN. § 48-10-103(a); N.D. Cent. Code AnN. § 14-15-10(1); Ohio Rev. Code AnN. $\S 3107.055(\mathrm{C}) ; 23$ Pa. Cons. Stat. AnN. § 2533(d); S.C. Code AnN. § 63-9-310(F); TenN. Code ANN. § 36-1-109; UTAH CODE ANN. § 76-7-203; W. VA. CODE ANN. § 48-22-803; Wis. STAT. ANN. $\S 48.913(1)$ (West 2008 \& Supp. 2009).

36. In many states, it is permissible for adoptive parents to pay for medical expenses, hospital expenses, maternity clothing, legal fees, prenatal care, counseling and mental examinations, placement fees, and any court costs relating to the birth of the child they intend to adopt. See, e.g., Ala. Code § 26-10A-34; Ariz. Rev. Stat. AnN. § 8-114(A); ConN. Gen. Stat. AnN. § 45a-728c (West 2004).

37. See, e.g., DeL. CodE ANN. tit. 13, § 928(b) (allowing an agency to charge a service fee "for each adoption in an amount not exceeding the cost of services rendered, to be paid by the adopting parent or parents"); KAN. STAT. ANN. § 59-2121(a) ("Except as otherwise authorized by law, no person shall request, receive, give or offer to give any consideration in connection with an adoption, or a placement for adoption, other than (1) reasonable fees for legal and other professional services rendered in connection with the placement or adoption not to exceed customary fees for similar services by professionals of equivalent experience and reputation where the services are performed ... (2) reasonable fees in the state of Kansas of a licensed child-placing agency.").

38. See Ala. Code § 26-10A-34; Ariz. Rev. Stat. Ann. § 8-114(A); Ark. Code Ann. § 9-9211 (West 2009); CAL. FAM. CODE $\S 8610$ (a) (West 2004); FlA. STAT. ANN. $§ 63.097(2)$; GA. CodE ANN. § 19-8-13(c) (West 2010); IDAHO CODE ANN. § 18-1511 (West 2006); 720 Ill. COMP. STAT. ANN. 525/4; IND. CODE ANN. § 35-46-1-9(b) (West 2004 \& Supp. 2010); KAN. STAT. ANN. § 592121(a); LA. Child. Code ANN. art. 1200(B); Me. Rev. STAT. ANN. tit. 18, § 9-306(a) (1998); MD. CODE ANN., FAM. LAW § 5-362(b); Mich. COMP. LAWS ANN. § 710.54(3) (West 2002); MinN. STAT. ANN. § 259.55 (West 2007); Miss. CodE ANN. § 43-15-23(4); Mo. ANN. STAT. § 453.075(1) (West 2003); Mont. Code AnN. § 42-7-101(1); Nev. Rev. Stat. AnN. § 127.287(3); N.H. Rev. Stat. AnN. § 170-B:13(1)(a); N.J. STAT. AnN. § 9:3-39.1(e); N.M. STAT. ANN. § 32A-5-34(B); N.Y. Soc. SERV. LAW § 374(6); N.C. GEN. STAT. ANN. § 48-10-103(e); N.D. Cent. CODE ANN. § 14-15-10(1); OHio Rev. Code ANN. § 3107.055(C); OKLA. Stat. AnN. tit. 10, § 7505-3.2; OR. ReV. Stat. AnN. $\S 109.311(1)$ (West 2003 \& Supp. 2010); 23 Pa. Cons. STAT. ANN. § 2533(d); S.C. CodE ANN. § 63-9-310(F); Tenn. Code AnN. § 36-1-109; Tex. Penal Code AnN. § 25.08(b) (West 2003 \& Supp. 2010); UtAh CODE ANN. § 76-7-203; VT. STAT. ANN. tit. 15A, § 7-103(a); VA. CodE ANN. $\S$ 63.2-1218; WASH. ReV. CODE ANN. § 9A.64.030(2) (West 2009); W. VA. CODE ANN. § 48-22803(e); Wis. STAT. ANN. § 48.913(1).

39. See Ariz. Rev. Stat. AnN. § 8-114(A); Conn. Gen. Stat. AnN. § 45a-728 (West 2004); 
adoption paperwork; $;^{40}$ and expenses for care of the child between birth and placement. ${ }^{41}$ Such fees are routinely accepted as permissible, even in states prohibiting the payment of "anything of value" in connection with the placement of a child for adoption. ${ }^{42}$ The central idea behind the allowance of such expenses - even in view of a widespread prohibition on baby selling - is that these expenses are necessary and direct consequences of the birth and placement of the child, ${ }^{43}$ which should be a

IND. CODE ANN. § 35-46-1-9(b); LA. ChILD. CODE ANN. art. 1200(B); ME. ReV. STAT. ANN. tit. 18A, § 9-306(a); Mich. Comp. Laws AnN. § 710.54(5); Minn. Stat. AnN. § 259.55; Miss. Code ANN. § 43-15-117(4); Mo. ANN. STAT. § 453.075(2); MonT. CODE ANN. § 42-7-101(1); N.H. Rev. Stat. AnN. § 170-B:13(1); N.J. STAT. AnN. § 9:3-39.1(e); N.M. Stat. AnN. § 32A-5-34(B); N.C. Gen. Stat. AnN. § 48-10-103(a); OKLa. Stat. AnN. tit. 10, § 7505-3.2; 23 PA. CONS. STAT. AnN. $\S 2533(\mathrm{~d})$; Tenn. Code AnN. § 36-1-109; Tex. Penal Code AnN. § 25.08(b); Utah Code AnN. $\S$ 76-7-203; VT. Stat. ANN. tit. 15A, § 7-103(a); VA. CODE ANN. § 63.2-1218; Wis. STAT. ANN. $\S 48.913(1)$

40. See Ala. Code § 26-10-4.1; ArIz. Rev. Stat. AnN. § 8-114(A); Ark. Code AnN. § 9-9211(a); Colo. Rev. Stat. AnN. § 19-5-213(1)(a); Del. Code AnN. tit. 13, § 928(b); Fla. Stat. ANN. § 63.097(2)(f)(1); IdAHO CODE ANN. § 16-1515(1); 720 ILl. CoMP. STAT. ANN. 525/4.1(g); Kan. Stat. ANN. § 59-2121(a)(1); Ky. Rev. StAT. AnN. § 199.590(6); LA. Child. Code AnN. art. 1200(B)(8); Me. Rev. STAT. ANN. tit. 18-A, § 9-306(a)(1); MD. CODE ANN., FAM. LAW § 5-362(b); Mich. COMP. LAWS ANN. § 710.54(3)(f); MinN. STAT. ANN. § 259.55(1); Miss. Code ANN. § 43-15117(4); Mo. AnN. Stat. § 453.075(1)(4); Mont. Code ANN. § 42-7-101(1)(i); N.H. ReV. STAT. ANN. § 170-B:13(1); N.J. STAT. ANN. § 9:3-39.1(e); N.M. STAT. ANN. § 32A-5-34(B)(6); N.Y. Soc. SERV. LAW § 374(6); N.C. GEN. STAT. ANN. § 48-10-103(a)(6); N.D. CENT. CODE § 14-15-10(1)(b); OHIo Rev. CODE ANN. § 3107.055(C)(3); OKLA. STAT. ANN. tit. 10, § 7505-3.2(B)(1); 23 Pa. Cons. STAT. ANN. § 2533(d)(4); S.C. CODE ANN. § 63-9-310(F)(5) (2010); TENN. CODE ANN. § 36-1-109 (1)(B)(i); Tex. Penal Code AnN. § 25.08(b); Utah CODE ANN. § 76-7-203; Vt. Stat. AnN. tit. 15A, § 7-103(a); VA. CODE ANN. § 63.2-1218; WASH. REV. CODE ANN. § 9A.64.030(2); W. VA. CODE ANN. § 48-22-803(e); Wis. STAT. ANN. § 48.913(1).

41. See Alaska Stat. AnN. § 25.23.090(a) (West 2007); Ariz. Rev. Stat. AnN. § 8-133; ARK. Code ANN. § 9-9-211(a); CAL. FAm. Code § 8610(a); Fla. STAT. ANN. § 63.097(2); GA. Code ANN. § 19-8-13(c); 720 ILl. Comp. Stat. ANN. 525/1; IOWA CodE AnN. § 600.9(2) (West $2001 \&$ Supp. 2010); KAn. StAT. AnN. § 59-2121(a); Ky. Rev. StAT. ANN. § 199.590(6); LA. Child. Code AnN. art. 1200(B); ME. Rev. Stat. AnN. tit. 18-A, § 9-306(a); MinN. Stat. AnN. § 259.55; Mont. Code ANN. § 42-7-101(1); N.H. Rev. StAT. ANN. § 170-B:10-a(1); N.M. STAT. ANN. § 32A-534(B); N.C. Gen. Stat. AnN. § 48-10-103(e); N.D. Cent. Code § 14-15-10(1); Ohio Rev. Code ANN. § 3107.10(c); OKLA. STAT. ANN. tit. 10, § 7505-3.2; 23 PA. CONS. STAT. ANN. § 2533(d); S.C. Code AnN. § 63-9-310(F); Tex. Penal Code AnN. § 25.08(b); Vt. Stat. AnN. tit. 15A, § 7-103(a); VA. CODE ANN. § 63.2-1218; W. VA. CODE ANN. § 48-22-803(e).

42. Compare ARIZ. REV. STAT. ANN. § 8-114(C) (prohibiting compensation for consenting to place a child for adoption), and IND. CODE ANN. § 35-46-1-9(a) (establishing the transfer of property for consent to adoption as a Class D felony), with ARIZ. REV. STAT. ANN. § 9-114(A) (allowing a court to approve any reasonable and necessary expenses incurred in connection with the adoption, including costs for medical and hospital care and examinations for the mother and child, counseling fees, legal fees, agency fees, living expenses, and any other costs the court finds reasonable and necessary), and IND. CODE ANN. §35-46-1-9(b) (allowing payment for attorney's fees, hospital and medical, agency fees, birth parent counseling, costs of housing, utilities, phone service, or any additional itemized necessary living expense for birth mother during the second or third trimester of pregnancy and not more than six weeks after birth, maternity clothing, travel expenses that relate to the pregnancy or adoption, and actual wages lost).

43. Douglas H. Reiniger, Ethical Considerations in Representing Birth Parents: Regulation of 
financially neutral transaction for any birth parent willing to make the difficult choice of concluding a pregnancy by placing the child for adoption. $^{44}$

One possible payment stands out from these others, however, as more controversial and worthy of additional scrutiny-namely, the payment of birth-parent living expenses during the period of pregnancy and perhaps even for some period after the birth of the child. The vast majority of states allows prospective adoptive parents and the agencies and lawyers with whom they work to facilitate adoptions - to pay rent, utilities, or other housing-related expenses of birth parents. ${ }^{45}$ Indeed, only five states forbid-either legislatively or judicially-all such payments. ${ }^{46}$ Still, state law varies rather significantly when it comes to precisely what living expenses adoptive parents can permissibly cover without crossing the line into an illegal child sale. Models of state regulation vary from allowing such payments without restriction to a complete ban, but laws tend to center around more moderate schemes, including sanctioning only the payment of "reasonable" living expenses, capping these expenses at a specific dollar amount or providing

Adoption Expenses, in AdOPTION LAW InSt. 2007, at 183, 185 (PLI Litig. \& Admin. Practice, Course Handbook Ser. No. 211, 2007).

44. See ACADEMY Of CAlifornia Adoption LAWYers, http://www.acal.org/ (last visited Oct. 7, 2010). The Academy describes payments from adoptive parents to birth parents for the purpose of making adoption as a "financially neutral option for the birth mother" rather than a money-making opportunity. Id.; see also Jennifer L. Watson, Growing a Baby for Sale or Merely Renting a Womb: Should Surrogate Mothers Be Compensated for Their Services?, 6 WhitTIER J. ChILD. \& FAM. ADVOC. 529, 539 (2007) (stating that these payments are merely compensation for the pregnancy, not for the child); cf. Hearings, supra note 3, at 17-18 (testimony of William Acosta, Deputy Comm'r, Div. of Servs., N.Y. State Dep't of Soc. Servs.) (describing financial pressures put on young mothers who change their minds after agreeing to give up a child). But cf. Zierdt, supra note 1, at 62 (advocating an end to "paternalistic compensation laws").

45. Ariz. Rev. Stat. AnN. § 8-114(A); CONN. Gen. Stat. AnN. § 45a-728c (West 2004); Fla. StAT. ANN. § 63.097(2)(a); IDAHO CODE ANN. § 16-1515(1); 720 ILl. COMP. STAT. ANN. 525/4.1(a); IND. CODE ANN. § 35-46-1-9(b)(5); IOWA CODE ANN. § 600.9(2)(d); KAN. STAT. ANN. § 592121(a)(6); LA. ChILD. Code AnN. art. 1200(B); Me. Rev. Stat. AnN. tit. 18-A, § 9-306(a); Mich. COMP. LawS ANN. § 710.54(3); MinN. STAT. ANN. § 259.55(1); Miss. CODE ANN. § 43-15-117(4); Mo. AnN. Stat. § 453.075(1); Mont. Code Ann. § 42-7-101(1); Nev. Rev. Stat. AnN. $\S 127.287(3)$ (West 2008); N.H. REV. STAT. ANN. § 170-B:13(1); N.J. STAT. ANN. § 9:3-39.1(e); N.M. STAT. ANN. § 32A-5-34(B); N.Y. SOC. SERV. LaW § 374(6); N.C. GEN. STAT. ANN. § 48-10103(a); N.D. CENT. CODE § 14-15-10(1); OHIO REV. Code ANN. § 3107.055; OKLA. STAT. ANN. tit. 10, § 7505-3.2; 23 PA. Cons. STAT. ANN. § 2533(d); S.C. COdE ANN. § 63-9-310(F); TENN. Code ANN. § 36-1-109; Utah CODE ANN. § 76-7-203; Vt. STAT. ANN. tit. 15A, § 7-103(a); VA. Code ANN. § 63.2-1218; WIS. STAT. ANN. § 48.913(1).

46. See Colo. Rev. Stat. AnN. § 19-5-213(1)(a) (West 2005 \& Supp. 2009); Del. Code AnN. tit. 13, § 928(a) (West 2006); MD. CODE ANN., FAM. LAW § 5-362(a) (West 2006); TEX. PenAL CodE ANN. § 25.08; In re Baby Girl D., 517 A.2d 925 (Pa. 1986); Thacker v. State, 889 S.W.2d 380 (Tex. App. 1994) (construing Texas statute as disallowing payments for housing-related expenses). 


\author{
numerically unlimited payments but only for a very short window of \\ time surrounding the birth of the child. ${ }^{47}$
}

47. See Conn. Gen. Stat. AnN. § 45a-728c (allowing living expenses up to \$1500); Fla. STAT. ANN. § 63.097(2)(a) (West 2005) (allowing reasonable living expenses for up to six weeks post-partum); IDAHO CODE ANN. § 18-1511 (allowing reasonable living expenses during pregnancy and for period not to exceed six weeks post-partum); 720 ILL. COMP. STAT. ANN. 525/4.1(a) (allowing reasonable living expenses for no more than 120 days prior to birth mother's expected date of delivery and for no more than sixty days after birth of child); IND. CODE ANN. § 35-46-1-9(b)(5) (allowing reasonable living expenses during second or third trimester of pregnancy and not more than six weeks after childbirth, not to exceed \$1000); IOWA CODE ANN. § 600.9(2)(d) (allowing living expenses for no longer than thirty days after birth); KAN. STAT. ANN. § 59-2121(a)(6) (allowing reasonable living expenses if incurred during or as a result of the pregnancy); LA. CHILD. CODE ANN. art. 1200(B)(7) (allowing living expenses for a reasonable time before birth and for no more than forty-five days after birth); ME. REV. STAT. ANN. tit. 18-A, § 9-306(a) (allowing living expenses for biological mother and child); MiCH. COMP. LAWS ANN. § 710.54(3)(d) (allowing living expenses for birth mother before birth and for no more than six weeks after birth); MiNN. STAT. ANN. § 259.55(4) (allowing reasonable living expenses if needed to maintain an adequate standard of living that birth mother is unable to otherwise maintain); MISS. CODE ANN. § 43-15-117(4) (allowing mother's reasonable living expenses); MO. ANN. STAT. § 453.075(1) (allowing living expenses if within the norms of the community in which the birth mother resides); MONT. CODE ANN. § 42-7101(1)(h) (allowing temporary living costs for birth mother); NEV. REV. STAT. ANN. § 127.287(3) (allowing necessary living expenses related to birth of the child); N.H. REV. STAT. ANN. § 170$\mathrm{B}: 13(1)(\mathrm{d})$ (allowing living expenses if necessary to maintain an adequate standard of living that birth mother is otherwise unable to maintain); N.J. STAT. ANN. § 9:3-39.1(e) (allowing living expenses of birth mother during period of pregnancy and for period not to exceed four weeks after termination of pregnancy); N.M. STAT. ANN. § 32A-5-34(B) (allowing living expenses of birth mother and dependent children for a reasonable time before birth or placement of the adoptee and for no more than six weeks after birth or placement of the adoptee); N.Y. SOC. SERV. LAW § 374(6) (allowing reasonable and actual expenses for housing for a reasonable time not to exceed sixty days before birth and later of thirty days after birth or thirty days after parental consent to adoption); N.C. GEN. STAT. ANN. § 48-10-103(a)(4) (allowing ordinary living expenses of birth mother during pregnancy and for no more than six weeks after birth); N.D. CENT. CODE § 14-15-10(1)(e) (allowing living expenses if needed to maintain an adequate standard of living that birth mother is unable to otherwise maintain); OHIO REV. CODE ANN. § 3107.055(C) (allowing living expenses of birth mother not to exceed $\$ 3000$ incurred during pregnancy through the sixtieth day after minor's birth); OKLA. STAT. ANN. tit. 10, § 7505-3.2 (allowing reasonable living expenses if incurred during adoption planning process or during pregnancy not to exceed two months after birth of minor or after consent of birth mother); 23 PA. CONS. STAT. ANN. § 2533(d) (allowing living expenses of birth mother for reasonable time before birth and for no more than six weeks after birth); S.C. CODE ANN. $\S 63-9-310(\mathrm{~F})(1)$ (allowing reasonable living expenses for a reasonable period of time); TENN. CODE ANN. §36-1-109(B)(i) (allowing reasonable and actual expenses for housing for a reasonable period not to exceed ninety days prior to or forty-five days after birth or surrender or parental consent to adoption); UTAH CODE ANN. § 76-7-203(1)(a)(iii)(B)(II) (allowing temporary living expenses during pregnancy or confinement); VT. STAT. ANN. tit. 15A, § 7-103(a)(9) (allowing living expenses of mother for reasonable time before birth and for no more than six weeks after birth); VA. CODE ANN. § 63.2-1218 (allowing reasonable and necessary expenses for shelter when birth mother unable to support herself); WiS. STAT. ANN. § 48.913(1)(i) (allowing living expenses of birth mother, not to exceed $\$ 5000$, only to protect welfare of birth mother or fetus). 


\section{A. The Gold Card: Expenses Without Limitation}

In view of general state prohibitions on baby selling, no state statute sanctions the payment of birth-parent living expenses while expressly describing those permissible expenses as unlimited. Rather, states sanctioning adoptive-parent payment of birth-parent living expenses often describe permissible payments in very general terms, such as those "related to the placement of the child." 48 Even when living expenses are expressly mentioned by statute, the trend is to simply say that adoptive parents may pay such expenses to birth parents without running afoul of state law criminalizing sales of a human being. ${ }^{49}$ Still, jurisprudence in a number of states indicates that courts are often willing to allow substantial - even unfettered - expenditures for living, so long as the birth family actually incurred the expenses. ${ }^{50}$

\section{B. "Reasonableness" and "Necessity" Limitations}

Far more common than statutes without any express boundaries for the payment of living expenses are laws that specifically sanction prospective adoptive parents' payment of birth-parent living expenses only when such expenses are "reasonable" or "necessary." At least twenty-one states have adopted such a rule. ${ }^{51}$ State law varies widely on

48. See, e.g., AlASKA STAT. ANN. § 25.23.090(a) (West 2007) (requiring adoptive parents to file report showing "any expenses incurred in connection with (1) the birth of the minor; (2) placement of the minor with petitioner; (3) medical or hospital care received by the mother or by the minor during the mother's prenatal care and confinement; and (4) services relating to the adoption or to the placement of the minor for adoption that were received by or on behalf of the petitioner, either natural parent of the minor, or any other person"); ARK. CODE ANN. § 9-9-211(a) (West 2009) (requiring a petitioner in a proceeding for adoption to file a full accounting report showing any expenses in connection with the birth of the child and placement for adoption); KY. REV. STAT. ANN. $\S 199.590(6)$ (West 2006) (stating a listing of expenses of the biological parent or parents for any purpose related to the adoption allowed may be submitted "for the court's approval or modification").

49. See ME. REv. StAT. ANN. tit. 18-A, § 9-306(a) (allowing living expenses for biological parents and child); MISS. CODE ANN. § 43-15-117(4) (stating "nothing . . precludes" the payment of mother's living expenses); OR. REV. STAT. ANN. § 109.311(1) (West 2003 \& Supp. 2010) (allowing living expenses related to the adoption).

50. See Brod v. Matter of An Adoption, 522 So. 2d 973, 978 (Fla. Dist. Ct. App. 1988) (allowing an intermediary to pay on behalf of adoptive parents the documented living expenses of a birth mother for thirty days post-natal). See generally 1 JACOBS, supra note 3, § 4.25 (discussing state laws that allow payment of living expenses).

51. See Ala. Code § 26-10A-23 (1992); Ariz. Rev. Stat. AnN. § 8-114(A) (2007); CAL. PENAL CODE $\S 273$ (b) (West 2008); FLA. STAT. ANN. § 63.097(2); IDAHO CODE ANN. § 16-1515(1); 720 Ill. COMP. Stat. ANN. 525/4.1(a); IND. CODE ANN. § 35-46-1-9(b); KAN. StAT. AnN. § 592121(a); Mich. COMP. LAws ANN. § 710.54(3); MinN. STAT. ANN. § 259.55; Miss. CodE ANN. 
the issue of what is reasonable and necessary, and some states provide no statutory guidance on the meaning of the terms in this context. Moreover, the timing of the reasonableness determination has a significant impact on the effectiveness of the rule in weeding out baby sales. Ironically, most states adopting a reasonableness or necessity test to review the propriety of expense payments select the time at which rational decisions about expense propriety are least likely to be madenamely, at finalization hearings. ${ }^{52}$ Other states provide for a determination of reasonableness or necessity at some earlier time. ${ }^{53}$

\section{The Meat of the Rule: What Expenses Are Reasonable or Necessary?}

Arizona gives what is perhaps the best guidance on the substantive limitations of reasonableness or necessity rules. That state's laws specifically provide that, in assessing living-expense payments, courts are to consider "the current standard of living of the birth parent," "[t]he standard of living necessary to preserve the health and welfare of the birth parent and the unborn child," and "the existence of alternative financial resources for the birth parent."

New Hampshire and Minnesota address similar issues but describe permissible living-expense payments in terms of loss of the birth parent's ability to maintain full employment for some period of the pregnancy. ${ }^{55}$ Both states' statutes define necessary expenses as those required to maintain the birth mother in the standard of living to which she is

§ 43-15-117(4); MONT. CODE ANN. § 42-7-101(1); NeV. REV. STAT. ANN. § 127.287(3); N.H. REV. Stat. ANN. § 170-B:13(I); N.M. STAT. ANN. § 32A-5-34(B); OKLA. STAT. ANN. tit. 10, § 7505-3.2; S.C. CODE ANN. § 63-9-310(F); TENN. CODE ANN. § 36-1-109; UTAH CODE ANN. § 76-7-203; VT. STAT. ANN. tit. 15A, § 7-103(a); VA. CODE ANN. § 63.2-1218.

52. See Ariz. Rev. Stat. AnN. § 8-114(B); CAL. Fam. Code § 8610(a) (West 2004); Fla. STAT. ANN. § 63.132; Mich. COMP. LAWS ANN. § 710.54(7); N.H. REV. STAT. ANN. § 170-B:19(V); N.M. STAT. ANN. § 32A-5-34(A); OKLA. STAT. ANN. tit. 10, § 7505-3.2(A); S.C. CODE ANN. § 63-9740; UtAH CODE ANN. § 78B-6-140; VT. STAT. ANN. tit. 15A, § 3-702.

53. See, e.g., ALA. CODE $\S 26-10 \mathrm{~A}-23$ (b) (requiring that adoptive parents submit to the court a full accounting of all charges for expenses before paying); ARIZ. REV. STAT. ANN. § 8-114(B) (requiring adoptive parents to obtain court approval before payment when living expenses exceed \$1000); 720 ILl. COMP. STAT. ANN. 525/4.1(e) (requiring that adoptive parents file a financial accounting report with the court within fourteen days of the payment of living expenses).

54. ARIZ. REV. STAT. ANN. § 8-114(B).

55. N.H. REV. STAT. ANN. § 170-B:13(I) (permitting payment of "[r]easonable living expenses of the birth mother which are necessary to maintain an adequate standard of living, which the birth mother is unable to otherwise maintain because of loss of income or other support resulting from the pregnancy and lost wages resulting from the pregnancy or delivery"); MINN. STAT. ANN. § 259.55 (allowing birth parent to receive "reasonable living expenses of the birth mother which are needed to maintain an adequate standard of living which the birth mother is unable to otherwise maintain because of loss of income or other support relating from the pregnancy"). 
accustomed but is unable to maintain because of loss of income or other support resulting from her pregnancy. ${ }^{56}$ The reasonableness and necessity inquiry in these states, then, is strongly tied to lost wages. Living expenses are essentially intended as a substitute for the lost wages, which come about as a result of the birth mother's decision to carry the baby to term. ${ }^{57}$

2. Procedural Hindrances: When Are Reasonableness and Necessity Determined?

Setting aside state law variations on the meaning of reasonable or necessary in the living expenses context, states still substantially diverge when applying these rules as a result of procedural considerations. Essentially, the question concerns the timing of a reasonableness or necessity finding.

If the purpose of imposing a limitation on permissible living-expense payments is to shield adoptions from perceived impropriety-essentially to persuasively rebuff serious charges of baby selling while still fostering the practice of adoption - then one might expect the determination of reasonableness or necessity to be made early on. Ideally, all parties involved in the triad, most particularly the potential adoptive parents, need to know what monies can permissibly change hands before any payments are made. Indeed, one New York court advised attorneys involved in child adoptions to obtain court approval before making expenditures related to birth mothers' pregnancies. ${ }^{58}$ Unfortunately, such a solution is impracticable. Courts generally are not permitted to issue advisory opinions, ${ }^{59}$ and at the stage when a prospective adoptive parent would need approval of living expenses yet to be paid, there would not yet be a court proceeding. ${ }^{60}$ A judicial proceeding related to an adoption is initiated only by petition ${ }^{61}$ after the birth and consent of the birth parents to the adoption. ${ }^{62}$ Thus, no case or controversy exists before the

56. See Douglas R. Donnelly, Adoption, in 2 Cal. Transactions Forms: Family LaW $\S 6: 20$ (2d ed. 2003).

57. See id

58. In re Adoption of Baby Boy M.G., 515 N.Y.S.2d 198, 258 (Sur. Ct. 1987).

59. For a discussion of the federal doctrine prohibiting advisory opinions and state law exceptions to it, see generally Jonathan D. Persky, Note, "Ghosts that Slay": A Contemporary Look at State Advisory Opinions, 37 CONN. L. REV. 1155 (2005).

60. See In re Adoption of Stephen, 645 N.Y.S.2d 1012, 1014 (Fam. Ct. 1996).

61. See, e.g., Kan. StAT. AnN. § 59-2128 (2005).

62. Id. § 59-2129(a) (Supp. 2009). 
birth of the child - when a prospective adoptive parent truly needs a judicial determination of reasonableness or necessity. ${ }^{63}$

The importance of this procedural posture for determining whether living expenses are reasonable is significant because it serves to undermine the effectiveness of the reasonableness rule in preserving the integrity of adoptions as a financially neutral transaction. ${ }^{64}$ The rules on advisory opinions, which prohibit judges from granting advance authorization for adoption-related payments, essentially place the question of propriety before the judge for the first time at the finalization hearing. In most cases, the child has already lived with the potential adoptive parents for a period of six months or a year by this time. ${ }^{65}$ Judges' options are limited in such scenarios. Refusing to grant the petition to finalize the adoption would be almost unconscionable, ${ }^{66}$ yet state law limiting a court's ability to order a birth parent to reimburse excessive fees may provide a judge no other "sanction" for the payment of living expenses that are not reasonable or necessary. ${ }^{67}$ The trend,

63. See Lucas, supra note 21, at 559 (arguing for earlier legislative determination of permissible living-expense payments).

64. See FAQ's About Birth Mother Expenses, ACADEMY OF CALIFORNIA AdOPTION LAWYERS (Sept. 13, 2003), http://www.acal.org/birth.htm (explaining that payments from adoptive parents to birth parents make adoption a financially neutral option for the birth mother rather than a moneymaking opportunity).

65. See Ariz. Rev. Stat. AnN. § 8-114(B) (2007); CAL. FAM. Code $\$ 8610$ (West 2004); Fla. Stat. ANN. § 63.132 (West 2005 \& Supp. 2010); IdAHO CODE ANN. § 16-1515 (West 2006); Mich. COMP. LaWS ANN. § 710.54(7) (West 2002); N.H. Rev. STAT. ANN. § 170-B:19(V) (Supp. 2009); N.M. Stat. ANN. § 32A-5-34(A) (West 2003 \& Supp. 2009); OKLa. STAT. AnN. tit. 10, § 75053.2(A) (West 2009); S.C. CODE ANN. § 63-9-740 (2010); TENN. CODE ANN. § 36-1-116(b)(16) (West 2009); UtAh Code ANN. § 78B-6-140 (West 2009 \& Supp. 2010); VT. STAT. ANN. tit. 15A, § 3-702 (West 2007) (requiring that an accounting be filed prior to the date set for the finalization hearing on the adoption petition); see also ARK. CODE ANN. § 9-9-213 (West 2009) (stating that a final decree of adoption may not be issued until the minor has lived in the petitioner's home for at least six months); NeV. ReV. STAT. ANN. $\$ 127.127$ (West 2008) (requiring that adoptive parents file an accounting report within fifteen days after the petition for adoption is filed or within five months after the child begins to live in their home).

66. See In re Adoption of Male Infant A., 578 N.Y.S.2d 988, 994 (Fam. Ct. 1991) ("In denying an adoption for violation of the adoption laws, a child may be deprived of the only home he or she has ever known and returned to a natural parent marginally capable of providing care for the child or placed into foster care."). Courts are reluctant to deny finalization of adoptions due to violations of the adoption laws regarding payment of expenses. See In re Carballo by Tersigni, 521 N.Y.S.2d 375, 377-78 (Fam. Ct. 1987); In re Juan P.H.C., 496 N.Y.S.2d 630, 632-33 (Sur. Ct. 1985).

67. See MinN. StAT. ANN. $§ 259.55$ (2) (West 2007) (“A contract purporting to require a birth parent to reimburse a prospective adoptive parent for [living expenses] under any circumstances ... is void as against public policy.”); MO. ANN. STAT. § 453.075(2) (West 2003) (stating that the court may decline to issue the decree of adoption if it finds that any payments were unreasonable); MONT. CODE ANN. § 42-7-105(4) (2009) ("It is illegal to require repayment or reimbursement of anything provided to a birth parent ....”); N.H. REV. STAT. ANN. § 170-B:13(II) (“A contract purporting to require a birth parent to reimburse an intended adoptive parent for [living expense] payments under 
then, is that the inquiry conducted at this stage is not truly a serious one, ${ }^{68}$ which undermines the structure of the rule itself as a means of ensuring that adoption does not become baby selling.

\section{Specific Monetary Caps}

Three states attempt to curb blurring of the lines between allowing payments of birth-parent living expenses and baby selling by imposing specific dollar limitations on living-expense payments that adoptive parents are permitted to make. ${ }^{69}$ For instance, Connecticut allows total birth-parent living expenses of no more than $\$ 1500$ in connection with the placement of a child. ${ }^{70}$ Wisconsin caps living expenses at a more generous $\$ 5000$ but requires that such payments be "necessary to protect the health and welfare of the birth mother or the fetus."71 Precisely what qualifies as "necessary" under that statutory language has not yet been considered by Wisconsin's courts.

any circumstances . . is void as against public policy.”); N.J. STAT. ANN. § 9:3-39.1(e) (West 2002 \& Supp. 2010) (stating that certain payments by adoptive parents are not a violation of law prohibiting payment in relation to placement of a child); WIS. STAT. ANN. $§ 48.837(6)$ (b) (West 2008 $\&$ Supp. 2009) (stating that the court may dismiss the adoption petition upon a finding of coercive payments). But see Mich. COMP. LAWS ANN. § 710.54(10), (11) (West 2002) (stating that acceptance or retention of amounts in excess of those approved of by the court constitutes a misdemeanor for the first violation and a felony for each subsequent violation); N.M. STAT. ANN. $\S 32 \mathrm{~A}-5-34(\mathrm{D})$ ("Any person who threatens or coerces a parent to complete relinquishment of parental rights or to complete the consent to an adoption... shall be liable to the parent for compensatory and punitive damages.”); OHIO REV. CODE ANN. § 3107.055(D) (West Supp. 2010) (stating that the court may reduce the amount of disbursements related to a minor's permanent surrender, placement, or adoption if it is unreasonable, or if disallowed, the court may order that it be refunded); OKLA. STAT. ANN. tit. 10, § 7505-3.2(A) (stating that if some fees or charges are unlawful or unreasonable, the court may order reimbursement and persons wishing to pay birth-mother living expenses must first obtain court authorization); S.C. CODE ANN. § 63-9-310(F) ("The court may approve an adoption while not approving unreasonable fees and costs."); VT. STAT. ANN. tit. 15A, $\S 3-703(a)(8)$ (stating that prior to granting an adoption, the court must deny, modify, or order reimbursement of any unauthorized payment or unreasonable or unnecessary payments).

68. Cf. In re Adoption of Child by I.T., 397 A.2d 341, 347-48 (N.J. Super. Ct. App. Div. 1978) (refusing to dismiss adoption petition despite statutory violations because the best interests of child outweighed any wrongdoing). But see ALA. CODE § 26-10A-23(b) (2009) (stating that prior to payment, adoptive parents must file an accounting of all expenses, and payment may be made only with court approval or payments may be placed in escrow until court approval); 720 ILL. CoMP. STAT. ANN. 525/4.1(e) (West 2010) (requiring that the adoptive parents file a final financial accounting with the court within fourteen days of payment of living expenses); MICH. COMP. LAWS ANN. § 710.54(10) (stating that courts will evaluate all fees and expenses and may disapprove of some).

69. See Conn. Gen. Stat. Ann. § 45a-728c (West 2004); Ohio Rev. Code Ann. $\S 3107.055(C)$; WIS. STAT. ANN. § 48.913(1).

70. Conn. Gen. Stat. AnN. $§ 45 \mathrm{a}-728 \mathrm{c}$. The court may approve an amount exceeding $\$ 1500$ "in unusual circumstances." Id.

71. Wis. STAT. ANN. § 48.913(1). 
Perhaps the most instructive body of state law on imposing particular caps as a means of controlling the payment of birth-parent living expenses in connection with adoptive placements is that in Ohio. Before late 2008, Ohio was one of just a handful of states altogether disallowing the payment of birth-parent living expenses in connection with the adoption of a child. ${ }^{72}$ Before 2008, Ohio law allowed prospective adoptive parents to pay medical expenses incurred around the time of the child's birth and legal expenses associated with the surrender and placement of the child, but all other payments to birth parents were prohibited as a violation of Ohio's baby-selling statute, which prohibits "any disbursements in connection with [a] minor's permanent surrender, placement, or adoption." "73 In December 2008, however, the Ohio legislature lifted its ban on the payment of living expenses to allow prospective adoptive parents, through agencies or attorneys only, to pay birth-mother living expenses not to exceed the sum of $\$ 3000 .^{74}$ Some Ohio adoption lawyers contended that the change was a positive one for Ohio, as couples were "losing babies" when birth mothers traveled out of the state to give birth to and place their children in states that did allow some expenditures for housing. ${ }^{75}$ Ohio's new law aligned it with that of Connecticut and Wisconsin, then, in attempting to strike a balance on the living-expense issue. Indeed, advocates of the new Ohio law specifically described it as a means of "help[ing] birth mothers and still maintain[ing] enough court oversight to prevent adoptions from becoming sales." 76

\section{Limitation to the "Period of Confinement"}

A number of states limit the payment of birth-parent living expenses, not with a reasonableness requirement or a cap on permissible expenditures but, rather, by limiting the period of time for which such expenses may be covered by potential adoptive parents. ${ }^{77}$ Indiana,

72. See OHIo Rev. Code ANN. § 3107.10 (C) (West 2005) (stating that "[n]o ... person ... shall make or agree to make any disbursements in connection with the minor's permanent surrender, placement, or adoption other than" those specifically authorized by the statute), amended by $\S 3107.055$ (c) (West Supp. 2010). The statute did not specifically authorize birth-parent living expenses, and these expenses were, therefore, not permissibly covered by adoptive parents.

73. Id. $\S 3107.10(\mathrm{C})$ (West 2005).

74. Sub. H.R. 7, 127th Gen. Assemb., 2008 Sess. (Ohio 2008).

75. Rita Price, Birth Moms Could Get Aid Under Bill—Ohio Loses Out on Adoptions over Living-Expenses Ban, Some Say, Columbus DisPatch, May 25, 2008, at 1A.

76. Id.

77. See Ind. Code ANN. § 35-46-1-9(b) (West 2004 \& Supp. 2010); 720 Ill. Comp. STAT. ANN. 525/4.1(a) (West 2010); N.Y. Soc. SERV. LAW § 374(6) (McKinney 2003 \& Supp. 2010); 
Illinois, New York, and Tennessee all regulate the payment of living expenses in this manner, allowing payment of rent, housing expenses, and the like within a specific, delineated period that ranges from sixty days in New York ${ }^{78}$ to perhaps as long as six months in Indiana. ${ }^{79}$ Still other states - including Pennsylvania, South Carolina, and Vermontallow the payment of living expenses for a "reasonable time" only, ${ }^{80}$ with state courts left to define the precise meaning of the phrase in this context only under the pressure of actual litigation. ${ }^{81}$

The idea behind these limitations based on an expense's proximity to the birth may not be immediately obvious. A glance at legislative history in the aforementioned states, however, indicates that states choosing this manner of regulating living-expense payments to birth mothers are trying to maintain the economic neutrality of the adoption transaction for birth mothers whose employment abilities may be diminished for a portion of the pregnancy. ${ }^{82}$ In keeping with this goal, at least one scholar has articulated that rules setting forth short windows for the payment of birth-parent living expenses should closely track the "period of confinement" associated with pregnancy. ${ }^{83}$ Whether that is done by setting out a period of days or by designating that expenses may be paid only for a reasonable time, the purpose of the rule is to serve as a sort of substitute for wages or other sources of income the birth mother may not receive because of the confinement associated with the pregnancy. ${ }^{84}$ To

TENN. CODE ANN. § 36-1-109 (West 2009).

78. N.Y. SOC. SERV. LAW § 374(6) (permitting payment of "reasonable and actual expenses for housing, maternity clothing, clothing for the child and transportation for a reasonable period not to exceed sixty days prior to the birth and the later of thirty days after the birth or thirty days after the parental consent to the adoption").

79. See IND. CodE ANN. §35-46-1-9(b). The Indiana statute speaks in terms of trimesters and allows the payment of birth-mother living expenses only in the second and third trimesters of pregnancy and up to six weeks post-natal. Id. Illinois allows the payment of such expenses for up to 120 days before the birth mother's expected due date "and for no more than 60 days after ... birth." 720 IlL. COMP. STAT. ANN. 525/4.1(a). Tennessee allows the expenditures for a maximum of "ninety (90) days prior to or forty-five (45) after the birth or surrender . . of the child." TENN. CODE ANN. § 36-1-109.

80. See 23 Pa. Cons. Stat. AnN. § 2533(d) (West 2001); S.C. Code AnN. § 63-9-310(F) (2010); VT. STAT. ANN. tit. 15A, § 7-103(a) (West 2007).

81. See, e.g., Lucas, supra note 21, at 561-62 (discussing the few reported cases where New York courts grappled with the permissibility of living expenses).

82. See, e.g., Donnelly, supra note 56, § 6:20 ("No [California] court... has ever defined 'confinement,' ... [but] the apparent legislative intent is to refer to the period of time during which the birth mother is disabled or unemployable due to pregnancy.").

83. See Joan Heifetz Hollinger et Al., Adoption Law And Practice $§ 5.09$ (1997).

84. See Donnelly, supra note $56, \S 6: 20$ (stating that adoptive parents may not reimburse the birth mother for lost income because "[m] ost birth mothers spend roughly the same amount as they earn on living expenses," but "payment by adopting parents for expenses has the same practical effect as reimbursement of [the birth mother's] lost income"). 
the extent a birth mother is unable to work during the final period of her pregnancy, the states allowing these expenses during a short window essentially allow her to maintain housing even without a traditional source of income.

Virginia has taken very seriously the notion of living expenses as a substitute for wages that can no longer be earned due to the demands of pregnancy. ${ }^{85}$ But instead of relying on a sixty- or ninety-day period before the birth of the child to appropriately limit these expenses, the Virginia legislature has expressly allowed adoptive parents to pay reasonable and necessary expenses for shelter, food, clothing, and the like only on proof of the "written advice of [a] physician, [that] the birth mother is unable to work or otherwise support herself due to medical reasons or complications associated with the pregnancy or birth of the child." 86 Because not all pregnancies leave birth mothers unable to work for any significant period, ${ }^{87}$ the Virginia rule is more tailored to addressing the concerns that led states to limit living-expense payments temporally in the first place.

New Hampshire and Minnesota are somewhat similar. Both states' statutes expressly provide for the payment of only necessary living expenses and do not delineate any particular window for the permissibility of these payments before the birth. ${ }^{88}$ At first glance, then, it would seem these two states should be categorized as those limiting the payment of living expenses by a determination of reasonableness or necessity rather than those employing a short window of time to impose a limitation. In reality, however, these two states are best described as a hybrid of the two models. Both states allow only the payment of necessary expenses, but necessity in those statutes is defined in terms of maintaining a standard of living for the birth mother that is adequate when she is unable to maintain such a standard herself because of lost wages or income. ${ }^{89}$ Of course, it is likely in states regulating solely with a time-period limitation that the same expenses would be covered under each formulation of the rule. After all, the demands of pregnancy for the

85. See VA. CODE ANN. § 63.2-1218(iii) (West 2002).

86. Id.

87. See Being Pregnant at Work, BABYCENTER (Sep. 2006), http://www.babycenter.com/ 0_being-pregnant-at-work_490.bc (stating that if the birth mother is a healthy woman having a normal pregnancy and working in a safe environment, she may be able to continue working until the day of delivery or close to it).

88. See Minn. Stat. AnN. § 259.55(1)(4) (West 2007); N.H. Rev. Stat. AnN. § 170-B:13(I) (Supp. 2009).

89. Both statutes authorize payment of living expenses necessary "to maintain an adequate standard of living.” MinN. STAT. ANN. § 259.55(1)(4); N.H. REV. STAT. ANN. § 1-70-B:13(I)(d). 
vast majority of women typically only render a woman unable to be employed toward the tail end of the pregnancy. ${ }^{90}$ Both articulations of the rule, then, strive to rebuff charges of baby selling by limiting the permissibility of such payments to the "period of confinement." State statutes focusing on lost income rather than a specific number of days before birth are just more likely to match the period of confinement precisely.

\section{E. Outright Bans}

Finally, a very small number of states prohibit prospective adoptive parents from paying the housing costs of the birth mothers altogether. With Ohio defecting in 2008 to a cap system, ${ }^{91}$ today only five states disallow the payment of living expenses entirely. ${ }^{92}$

Texas law provides an instructive example of such a ban. A criminal statute in Texas defines the offense of "[s]ale or purchase of [a] child" as offering to accept, agreeing to accept, or accepting "a thing of value for the delivery of the child to another or for the possession of the child by another for purposes of adoption." 93 The statute goes on to list exceptions to "thing[s] of value," including agency fees, medical expenses, legal expenses, and even "necessary" pregnancy-related expenses - which may be read to include living expenses - but only if such expenses are "paid by a child-placing agency." 94 Thus, birthmother living expenses may be paid in Texas agency adoptions, though not in private adoptions. There is no exception to the Texas baby-selling statute which would permit the payment of living expenses directly from a prospective adoptive parent to a birth parent, even using an attorney as an intermediary.

In DeJesus v. State, the defendant birth mother was convicted of violating the Texas Penal Code for selling her child to her attorney, Thacker, the defendant in a sister case. ${ }^{95}$ The evidence showed that

90. See Donnelly, supra note 56, § 6:20 (classifying this period as the last trimester of pregnancy and sometimes up to six weeks postpartum).

91. See OHIO Rev. Code ANN. § 3107.055(C) (West Supp. 2010).

92. Colo. Rev. Stat. AnN. § 19-5-213(1)(a) (West 2005 \& Supp. 2009); Del. Code AnN. tit. 13, § 928(a) (Supp. 2010); MD. CodE ANN., FAM. LAw § 5-362(b) (West 2006); In re Baby Girl D., 517 A.2d 925 (Pa. 1986); DeJesus v. State, 889 S.W.2d 373 (Tex. App. 1994); Thacker v. State, 889 S.W.2d 380 (Tex. App. 1994).

93. Tex. PenAl Code AnN. § 25.08(a)(2) (West 2003 \& Supp. 2010).

94. Id.

95. 889 S.W.2d at 375 . At the time DeJesus was decided, the Texas statute criminalizing baby selling did not allow for the payment of necessary pregnancy-related expenses. Id. Rather, 
Thacker paid DeJesus $\$ 12,000$ for a relinquishment of parental rights for five of her children aged newborn to four years old. ${ }^{96}$ DeJesus asked for a jury instruction that she should be found not guilty if the jury found that she received the money as a reimbursement for living expenses, including housing, food, and clothing, but the trial court denied the jury instruction. ${ }^{97}$ The appellate court held that the trial court properly denied the instruction, as the payment of living expenses is not an express statutory exception to the ban on "baby selling." "98 The Texas appellate court upheld the defendant's conviction. ${ }^{99}$

In Pennsylvania, adoptive parents sought reimbursement of "unusual" fees paid to their intermediary agency after completion of an adoption. ${ }^{100}$ Those fees included $\$ 50$ per week in birth-mother housing expenses, paid not for the housing of the woman whose child they planned to adopt - that would clearly violate Pennsylvania's baby-selling statute-but rather for another pregnant woman planning to relinquish her child for adoption through the same agency. ${ }^{101}$ The Court of Appeals upheld the trial court's order requiring the agency to reimburse the adoptive parents for these housing expenses, calling the arrangement an "attempted subterfuge" that would permit a birth parent to profit impermissibly from an adoption. ${ }^{102}$

\section{THE FAILURE OF EXISTING SOLUTIONS tO THE LIVING-EXPENSES PROBLEM}

The nearly overwhelming predilection of states to allow prospective adoptive parents to pay some birth-mother living expenses is disturbing when one begins to seriously analyze both the impression these rules create and their real-world pragmatic effects. The rules regarding birthmother living expenses help none of the players involved in domestic adoption. Payments for housing and other related expenses send the

\footnotetext{
exceptional payments were limited to agency, legal, and medical fees. Id. The pregnancy-related expense provision was added in 2001. Tex. Penal CODE ANN. § 25.08. Still, this exception extends only to pregnancy-related expenses paid by a licensed adoption agency. See id. Thus, the payments from prospective adoptive parents' attorney to the birth mother in DeJesus would violate even the current Texas statute.

96. DeJesus, 889 S.W.2d at 377

97. Id. at 379 .

98. Id.

99. Id. at 380.

100. In re Baby Girl D., 517 A.2d 925 (Pa. 1986).

101. Id. at 928.

102. Id.
} 
wrong message about adoption, fostering an all-too-easy analogy to baby selling and possibly even causing long-term damage to society in the form of exacerbating existing class and race divisions. Birth parents, ironically, may also suffer from receipt of these payments, as they tend to interfere with the voluntariness of surrenders. The impact on prospective adoptive parents of the allowance of such payments is demonstrably significant and negative. And because living-expense rules make prospective adoptive parents less likely to pursue domestic adoption, they harm children as well.

\section{A. The Thin Line Between Child Sales and Housing Payments}

One significant problem with a scheme of rules that generally allows the payment of birth-mother living expenses is that the payment of these sums tends to obfuscate the already thin line between mere assistance and baby selling. ${ }^{103}$ Unlike other adoption-related expenses, allowing prospective adoptive parents to pay birth-mother living expenses actually allows the birth mother to profit from the adoption transaction. And while such profit may seem acceptable when the child is successfully placed and all members of the triad are pleased with the outcome, serious societal harms result, most particularly along lines of race and class.

\section{Living Expenses as Gray-Market Activities}

To prohibit child trafficking, state statutes generally speak in terms of prohibiting persons from giving or receiving "money or other consideration or thing $[\mathrm{s}]$ of value" 104 in connection with the adoption of a child. $^{105}$ Medical expenses, legal expenses, and even living expenses incurred during the period of pregnancy and for a short time after the adoption are clearly covered, and thus prohibited, under the plain language of state baby-selling statutes. But these expenses are generally

103. See End Baby Commerce, Commentary, GAMBIT WKLY., June 10, 1999, at 7.

104. See, e.g., Colo. Rev. StAT. ANN. § 19-5-213(1)(a) (West 2005 \& Supp. 2009).

105. See, e.g., IowA CODE ANN. § 600.9(1) (West $2001 \&$ Supp. 2010) (“A biological parent shall not receive anything of value as a result of [adoption] ...."); LA. REV. STAT. ANN. § 14:286 (West 2004) ("[I]t shall be unlawful ... to sell or surrender a minor child to another person for money or anything of value, or to receive a minor child for such payment of money or anything of value.”); MD. CODE ANN., CRIM. LAW § 3-603(a) (West 2002) (“A person may not sell, barter, or trade, or offer to sell, barter, or trade, a minor for money, property, or anything else of value."); Mo. ANN. STAT. § 568.175(1) (West 1999) ("[T]he crime of trafficking in children [is committed when one] offers, gives, receives or solicits any money ... for the delivery or offer of delivery of a child to another person, ... institution, . . or other organization for purposes of adoption ...."). 
viewed as exempt from the ambit of baby-selling prohibitions because of the need to protect the economic neutrality of the adoption transaction. ${ }^{106}$ The gist of this view is that a birth mother should not be placed in a better position by a match with a prospective adoptive family. ${ }^{107}$ At the same time, concerns about whether a birth mother would choose adoption were she to emerge from a pregnancy and adoptive placement worse off financially-particularly given the legal availability of abortion as an alternative ${ }^{108}$ - have led state legislators to err on the side of striving for economic neutrality. ${ }^{109}$

A further justification often espoused for allowing prospective adoptive parents to cover some birth-parent living expenses during the period leading up to the birth and adoption is that prospective adoptive parents have a strong interest in adopting a healthy child. ${ }^{110}$ Ensuring that the birth mother is well cared for is the best way to promote the birth of a healthy baby. ${ }^{111}$ When it comes to medical expenses, for instance, this line of thinking is rather easily supported. A birth mother who receives adequate prenatal care and competent medical assistance during the birth of the child is more likely to deliver a healthy newborn. ${ }^{12}$ Viewed through this lens, the payment of some pregnancy-related expenses by adoptive parents serves only to promote the health and safety of the birth mother, and by extension, the baby she carries. Payments made solely to safeguard health and promote the welfare of the birth mother and child do not often raise red flags. Most would not argue that a prospective adoptive parent's payment of the birth mother's $\$ 5000$ hospital bill for the child's delivery would even come close to baby

106. See ACADEMY OF CALIFORNIA AdOPTION LAWYERS, supra note 44; see also Watson, supra note 44 , at 539 .

107. See ACAdemy of California Adoption LaWyers, supra note 44; see also Donnelly, supra note $56, \S 6: 20$.

108. See generally Roe v. Wade, 410 U.S. 113 (1973) (holding a statute prohibiting abortion unconstitutional).

109. See Donnelly, supra note $56, \S 6: 20$

110. See, e.g., Hendrix v. Hunter, 110 S.E.2d 35, 38 (Ga. Ct. App. 1959); Barwin v. Reidy, 307 P.2d 175, 184 (N.M. 1957); see also 720 ILl. COMP. STAT. ANN. 525/4.1(c) (West 2010) (permitting living expenses only in those circumstances where need is demonstrated for the payment of such expenses to protect the health of the biological parents or the health of the child to be adopted).

111. See Barwin, 307 P.2d at 184 (reasoning that "it is productive of the welfare of the child that the child and mother have adequate medical attention"). For a discussion of the health risks of pregnancy, see Klinke, supra note 26, at 143-45.

112. See Donald A. Rea, Note, Family Law-Adoption: Do Laws Prohibiting Reimbursement to a Natural Mother for Reasonable Expenses Incurred During Pregnancy Truly Serve the Best Interests of the Child?, 22 U. BALT. L. REV. 133, 138 (1992) (stating that the medical-expense exception "is permitted because it is deemed to directly benefit the child's best interests"). 
selling. ${ }^{113}$ Expenses related to health and safety simply are not often negatively perceived-likely because of adherence to the goal of financial neutrality for the birth mother in the adoption transaction.

These legislative goals of economic neutrality and narrowing permissible adoption-related expenses to those that affect the health or safety of the birth mother are nicely achieved when one considers medical, and even legal, expenses incurred in connection with adoption. These expenses can be definitively and demonstrably tied to the pregnancy, birth, and placement of the child. ${ }^{114}$ They are direct expenses connected solely with the birth and adoption. Hospital fees associated with the child's birth, for instance, would not be incurred absent the birth mother's pregnancy and her decision to carry the baby to term. Legal fees associated with the placement of the child and finalization of the adoption would not be incurred absent the birth mother's implementation of her adoption plan. These are truly expenditures which would not be made but for the continued pregnancy, birth, and subsequent adoption. Allowing prospective adoptive parents to cover these expenses, then, ensures that the birth mother neither profits nor suffers economically as a result of the choices she makes. ${ }^{115}$

With living expenses, however, the same rationale is unpersuasive. Those advocating the permissibility of living-expense payments in connection with domestic adoption uniformly proffer the justification of creating financial neutrality for the birth mother in the adoptive placement. ${ }^{116}$ But such arguments consistently ignore the fact that prospective adoptive parents' payment of the birth mother's housing expenses almost certainly provides an advantage that the birth mother would not have absent the pregnancy. Unlike medical expenses relating to birth or legal expenses relating to the execution of a surrender, living expenses - particularly housing costs - are not expenses with any causal connection either to pregnancy or to adoptive placement. Whether they are pregnant or not, whether they have created an adoption plan or not, and regardless of personal circumstances, all persons endure the hardship of either paying for adequate housing or relying on the charity of friends or social-welfare programs. Pregnancy does not transform that responsibility because the responsibility is not one related to the birth or adoption plan of the birth mother, except perhaps during a short and

113. See Barwin, 307 P.2d at 184 (reasoning that there is nothing "inimical to public policy" in allowing adoptive parents to pay the medical expenses of the birth mother).

114. See Rea, supra note 112, at 138 .

115. See ACADEMY OF CALIFORNIA AdOPTION LAWYERS, supra note 44.

116. Id.; see also Watson, supra note 44, at 539. 
rarely occurring ${ }^{117}$ window during which a birth mother's pregnancyrelated health complications preclude her from working to earn income necessary to pay for housing. ${ }^{118}$ For the vast majority of pregnancies, the ability of a birth mother to charge prospective adoptive parents for the costs of living she would have otherwise had to bear herself makes for an anything-but-neutral transaction. Particularly in states without any dollar cap or time limit imposed on living expenses, prospective birth parents stand to reap relatively substantial financial gain through the deflection of financial responsibility for their housing needs. ${ }^{119}$ The gain may not come in the form of a cash infusion directly to the birth mother, but the financial gain is no less substantial when it is achieved through the birth mother's indirect enjoyment of cost-free living, often limited only by a requirement that prospective adoptive parents cover only living expenses actually incurred. ${ }^{120}$ With the rationale of fiscal neutrality gone, it is difficult to draw any meaningful line between the conduct of providing a housing benefit to a birth mother and simply giving her a cash payment of the same amount to use in any manner she wishes.

Moreover, the desire to protect the health and safety of the birth mother, and thereby her unborn child, is an equally weak argument in favor of allowing such a clear economic boon to birth mothers. Living expenses simply are not like medical expenses insofar as they cannot so clearly be cabined as impacting the health of the child to be adopted. ${ }^{121}$ Those who would permit the payment of living expenses argue that "the public policy behind permitting [living] expenses is the assumption that a pregnant mother who is housed and fed will give birth to a healthier baby than a mother who is not." ${ }^{\text {"22 }}$ This assumes that the only possibilities are homelessness or a home provided by prospective adoptive parents and, likewise, starvation or food provided by prospective adoptive parents. Reality is likely to provide a much less stark contrast between alternatives. And given that reality, a problem of line-drawing becomes obvious rather quickly. A whole panoply of needs may be viewed-

117. See Being Pregnant at Work, supra note 87 (noting that if the birth mother is a healthy woman with a typical pregnancy working in a safe environment, she may be able to continue working until the day of delivery or close to it).

118. See Donnelly, supra note 56, § 6:20.

119. See ARK. Code AnN. § 9-9-211(a) (West 2009); Ky. Rev. Stat. AnN. § 199.590(6) (West 2006); Me. Rev. Stat. AnN. tit. 18-A, § 9-306(a) (1998); Miss. CODE ANN. § 43-15-117(4) (West 2008); OR. REV. STAT. ANN. § 109.311(1) (West 2003 \& Supp. 2010).

120. See, e.g., KY. REV. STAT. ANN. § 199.560(6).

121. Cf. In re Adoption No. 9979, 591 A.2d 468, 473 (Md. 1991).

122. Adoption House, Inc. v. P.M., No. 02-12-07TN, 00-37796, 2003 WL 23354141, at *9 (Del. Fam. Ct. Oct. 9, 2003). 
albeit with a liberal lens - to affect the health and welfare of the birth mother and therefore the fetus she carries. Clothing, for instance, has been likened to shelter insofar as both may be viewed as impacting the health and welfare of the birth mother. ${ }^{123}$

Are we then to sanction provision by adoptive parents of a halcyon environment and delectable foods for expectant mothers on the grounds these are beneficial to the child? If medical science were to determine that stress during pregnancy was inimical to the fetus, and an expectant mother's employment were causing her stress, would prospective adoptors be expected to employ an agency to find the mother a happier work environment, or perhaps simply support the mother during her pregnancy lest the added stress inhibit the baby's development or effect his insufferable disposition? ${ }^{124}$

The slippery slope from living expenses down to outright baby selling is indeed a steep one, and when such expenses are allowed based on a thin health or welfare justification, it is difficult to imagine why similar arguments could not be made just as persuasively for a host of disturbing expenses-a large, safe vehicle, ${ }^{125}$ an exercise club membership, and frequent massages. ${ }^{126}$ In short, allowing the payment of living expenses when they are neither but-for expenses of the pregnancy nor expenses that can seriously be said to affect the welfare of the child for whom adoption is considered makes the adoption a veiled transaction which comes alarmingly close to a child sale.

\section{The Harm of the Victimless Crime}

Philosophically, a lot of people feel that the violation of adoption laws [in the form of impermissible payments to the birth mother, for instance] is a victimless crime. The status of the child is improved.

123. In re Adoption No. 9979,591 A.2d at 468 (noting that lack of clothing could have an adverse effect on the health and welfare of the natural mother and unborn child as well); $i d$. at 481 (Eldridge, J., concurring) (arguing that the legislative history of the prohibition shows that the statute should not be construed to ban a small payment for maternity clothes).

124. In re Baby Girl D., 517 A.2d 925, 929 (Pa. 1986)

125. See, e.g., In re Adoption of Alyssa, L.B., 501 N.Y.S.2d 595, 596 (Sur. Ct. 1986) (considering adoptive parents' payment for the purchase of an automobile for birth mother).

126. The Academy of California Adoption Lawyers defined pregnancy-related living expenses to include maternity clothing, housing that is consistent with the birth mother's usual lifestyle, groceries, and transportation payment assistance. See FAQ's About Birth Mother Expenses, supra note 64 . 
The adoptive parents are getting what they want, and typically, the mother who wants to place the child places the child." 127

Even if state law creates a situation in which prospective adoptive parents frequently straddle the thin line between merely covering a birth mother's housing expenses and buying a baby, many would ask, Who cares? What, precisely, is the harm?

Margaret Jane Radin, in her well-known piece Market-Inalienability, persuasively catalogues the potential harm to society as a whole flowing from commodification of infants. ${ }^{128}$ Radin describes a number of harms, all injurious to the very notion of personhood itself. One such harm is that commodifying infants means placing a dollar value on them, and these value determinations will be made in a manner "injurious to their personhood and to the personhood of those who buy and sell on this basis, exacerbating class, race, and gender divisions." 129 Transported to the living-expenses context, this theory seems to hold quite strongly. There is already no doubt that birth mothers who will give birth to white infants are more highly sought after in the domestic-adoption arena than are pregnant women who will deliver African-American or mixed-race babies. $^{130}$ This reality is likely to persist simply because more prospective adoptive families wish to raise white infants, likely owing to the fact that the vast majority of prospective adoptive parents are themselves white. ${ }^{131}$ Probably little can be done-at least until society

127. Gabriel Escobar, Lawyer's Kidnap Case Spotlights Louisiana Adoption Laws, WASH. POST, Nov. 16, 1998, at C1, C6.

128. Margaret Jane Radin, Market-Inalienability, 100 HARV. L. REV. 1849, 1851-52 (1987).

129. Id. at 1927; see also Barbara K. Rothman, Reproductive Technology and the Commodification of Life, in EMBRYOS, ETHICS AND WOMEN's RIGHTS 96-97 (Elaine Hoffman Baruch et al. eds., 1988) (arguing that commodification in the surrogacy context affects women's self-respect and self-worth).

130. See Julie Palermo, Comment, Whose Child Is This? A Critical Look at International Adoptions that Fail, 20 IMMIGR. \& NAT'LITY L. REV. 713, 716 (1999) (“[A]s only a quarter of the children waiting for adoption are labeled white, it is almost impossible for white parents to adopt [a white infant] domestically without extensive waiting periods."); see also Adoption House, Inc. v. P.M., No. 02-12-07TN, 00-37796, 2003 WL 23354141, at *4 (Del. Fam. Ct. Oct. 9, 2003) (noting that the prospective adoptive family decided against adoption at the hospital during the child's birth after learning the child was biracial).

131. See Amanda Spake, Adoption Gridlock, U.S. News \& World ReP., June 22, 1998, at 30 (explaining that more Caucasian parents are interested in adoption than minority parents); William Tyree, The Business of International Adoption, JAPAN TIMES, June 9, 1999, available at http://search.japantimes.co.jp/cgi-bin/fv19990609a2.html (explaining that the fact that Caucasian parents seek to adopt more than minority parents has led to competition in the United States for Caucasian infants and approximately eighty percent of those seeking to adopt from Russia do so because of their desire for a child from the same race). 
moves further toward a racially neutral view of the family - to modify that demand.

But allowing prospective adoptive parents to pay birth-mother living expenses simply further striates existing racial divisions. Because a birth mother's receipt of living expenses is not a financially neutral transaction, ${ }^{132}$ white birth mothers are likely to be well-supported and even to financially benefit from cost-free housing during pregnancythereby improving their economic positions - while birth mothers in the racial minority are likely to continue unsupported. The message that white infants and white birth mothers are "worth more" is precisely the type of perceptual injury to personhood that Professor Radin describes in the context of baby selling. ${ }^{133}$ The risk of the damage caused by the transaction is strong enough to break the link between the payment of living expenses and baby selling entirely by prohibiting the payment of housing and other related expenses of the birth mother in connection with adoption.

\section{B. The Infringement on Voluntariness}

Even aside from its tie to baby selling, society should be concerned about the payment of birth-mother living expenses because of the serious questions state laws on this issue raise with regard to the voluntariness of birth-mother consent, and thus, the integrity of the entire adoptive placement. ${ }^{134}$ Just how free is the surrender of a child for adoption given by an emotionally fragile and exceptionally poor woman ${ }^{135}$ who sees the possibility of economic reward as a way out of her situation? Prohibitions on baby selling were adopted "to deter the potentially coercive effect of payments to expectant mothers at a time when the best

132. See supra Part III.A.1.

133. See Radin, supra note 128, at 1932 (arguing that women's attributes, such as height, eye color, race, intelligence, and athletic ability, will be monetized, and surrogates with "better" qualities will command higher prices as a result); see also Nancy Gibbs, The Baby Chase: No One Ever Said Adoption Was Easy - But as the Market Tightens and Competition Soars, Options for Parents Are More Intricate than Ever, TIME, Oct. 9, 1989, at 86 ("[A]doptive parents won't blink an eyelash over paying $\$ 20,000$ to $\$ 30,000$ for a healthy white baby.”).

134. See Hearings, supra note 3, at 13 (statement of Pamela Zekman, Investigative Reporter, Chi. Sun-Times) (reporting that girls involved with certain baby brokers who received various forms of compensation were pressured not to change their minds about relinquishing consent because they would have to pay thousands of dollars in reimbursement).

135. See Lisa Kelly, West Virginia's Adoption Statute: The History of a Work in Progress, 102 W. VA. L. REV. 1, 17 (1999) (claiming that birth mothers are often "poor, illiterate, and young"). 
interests of the child, and for that matter the mother and father, are most likely to be subordinated by greed or ulterior motives."136

Of course, there is not a serious question of voluntariness in every adoption case, and the existence of state law allowing prospective adoptive parents to cover birth-parent expenses of any kind does not necessarily create a lack of consent. But the risk of the coercive effects of payments is high, and it necessarily affects poor women disproportionately, as they are most likely to consider relinquishing their children for adoption and are most likely to need and be influenced by cash payments. ${ }^{137}$ That class effect, in and of itself, should give us pause. Professor Radin argues that the sale of "personal things" by those in poverty should necessarily be presumed to result from a lack of free choice. ${ }^{138}$ And "to protect the integrity of the adoption proceedings and to safeguard the best interests of the child," $" 139$ every possible step should be taken to ensure birth-mother voluntariness.

\section{The Discouragement of Quality Adoptive Parents}

One of the most controversial issues surrounding adoption, particularly in the last twenty years, is the growing trend of American parents seeking to adopt internationally rather than pursuing domestic adoption in the United States. ${ }^{140}$ The problem, as many see it, is that this decision to go abroad to build a family necessarily means, at least for each child adopted internationally by American parents, a child in need in the United States is left without an adoptive home. ${ }^{141}$ This view is supported by recent statistics. In the year 2002 alone, approximately 21,378 children from abroad were adopted into American families, an increase of 15,719 from 1999. ${ }^{142}$ During a similar period, however, domestic infant adoptions declined significantly, with experts estimating that in 2002, approximately 1246 fewer babies were adopted by American families than in $1996 .{ }^{143}$ Many often complicated reasons may

136. Thacker v. State, 889 S.W.2d 380, 386 (Tex. App. 1994) (quoting In re Thacker, 881 S.W.2d 307, 309-10 (Tex. 1994)).

137. Cf. Kelly, supra note 135, at 17 ("Often, [plaintiffs in fraud or duress cases are] poor, illiterate, and young birth mothers.").

138. See Radin, supra note 128 , at 1910.

139. ALA. CODE $\S 26-10$ A-34 cmt (2009).

140. See Palermo, supra note 130, at 713-14.

141. See id. at 715 .

142. See Total Adoptions to the United States, supra note 5.

143. Paul Placek, National Adoption Data, in ADOPTION FACTBOOK IV, supra note 2, at 3, 6. 
explain why prospective adoptive parents have increasingly chosen a global route when it comes to adoption. ${ }^{144}$ One of those reasons is the financial drain, and worse, financial uncertainty surrounding domestic infant adoption. ${ }^{145}$ There is a strong economic incentive to go international. And because expenses paid to birth parents are almost always one of the most substantial items of cost in a domestic adoption, ${ }^{146}$ reevaluation of the propriety of these payments at a time of rather widespread dissatisfaction with the domestic adoption system seems long overdue.

Far and away the most significant downside of the infant-domesticadoption scheme in this country, at least from the prospective-adoptiveparent perspective, is that the transaction has no guarantee of completion, even once the prospective parents expend large sums of money. ${ }^{147}$ Domestic infant adoption these days often costs as much as $\$ 40,000 .^{148}$ And while the total cost of an international adoption typically comes in at a pricier $\$ 50,000,{ }^{149}$ largely because of travel costs ${ }^{150}$ it is still viewed in adoption circles as a more stable financial bet. ${ }^{151}$ In the international adoption arena, with very few exceptions, those who enter the process, pay the requisite fees, and are found to be suitable adoptive parents succeed in bringing a child into their families. International adoptions begun are said to complete roughly eighty-six percent of the time. ${ }^{152}$

144. See Richard R. Carlson, Transnational Adoption of Children, 23 TulSa L.J. 317, 317 (1988) (arguing that the increase in popularity of transnational adoptions is caused by the "shortage of healthy adoptable infants born in the United States"); Palermo, supra note 130, at 717 (stating that "adoption is not a priority of public child welfare agencies," which focus on "preserving troubled families and addressing the problems in the growing foster care population"); Tyree, supra note 131 (stating that some prospective parents turn to intercountry adoption because it is quicker than domestic adoption).

145. See Lucas, supra note 21, at 555-56.

146. See id. at 556 ("Independent adoptions are so costly because state law permits adoptive parents to pay for the birth-parents' pregnancy-related expenses."); see also Gearino, supra note 7.

147. See Hollinger, supra note 27, at 49 ("Because payments [to birth parents] are not contingent on ... consent or the completion of an adoption, prospective adopters assume the risk of not being reimbursed for expenses they have paid ....").

148. See Costs OF AdOPTING, supra note 8.

149. See generally Adopting in Ontario: International Adoption, AdOPTIVEPARENTS.CA, http://www.adoptiveparents.ca/on_intadoption.shtml (last visited Oct. 7, 2010).

150. See Richard Mintzer, Yes, You Can Adopt! A Comprehensive Guide to Adoption 23-24 (2003).

151. See id. at 23 .

152. See Cost of Adoption Update, AdOPTIVE FAMILIES, http://www.adoptivefamilies.com/ articles.php?aid=1685 (last visited Oct. 7, 2010); see also MARY ANN LAMANNA \& AGNES Riedmann, Marriages and Families: Making Choices in a Diverse Society 260 (10th ed. 2009).

Intercountry politics plays a huge role in international adoptions, and there is always the risk 
There are never any guarantees surrounding the availability of a particular child for whom prospective adoptive parents begin the adoption process. But even if that particular child is determined to be unavailable for adoption, another adoptable child is typically identified, ${ }^{153}$ and prospective adoptive parents generally pay a previously agreed-upon agency fee for a near certainty that they will return with a new member of the family. ${ }^{154}$

Domestic adoption, meanwhile, is fraught with uncertainty. ${ }^{155}$ And while the cost may appear lower, ${ }^{156}$ that apparent financial incentive to adopt domestically is almost entirely neutralized by evidence of final placement rates. ${ }^{157}$ Because adoption agencies are not compelled to report and no government agency compiles statistics on failed adoptions, there is no perfect data detailing domestic adoption failure rates. ${ }^{158}$ Nonetheless, industry experts estimate that as many as half of the matches made between birth and prospective adoptive families fail. ${ }^{159}$ Birth mothers who create adoption plans with prospective adoptive families or adoption agencies later decide to parent their children themselves nearly eighty percent of the time. ${ }^{160}$ And lest one assume that the ultimate fulfillment of a birth mother's adoption plan is completely unrelated to the payment of her living expenses, "[1] ong and often bitter experience has repeatedly demonstrated that the birth mother who is most financially demanding is also the birth mother who is most likely to fail to complete the adoption plan."161

for prospective adoptive parents that the country from which they choose to adopt will close for foreign adoptions after their adoption process has begun. That risk can be substantially minimized, however, if prospective adoptive parents select a long-running program with current political support in the country of origin. Colombia and Korea, for instance, have long been perceived as operating such programs. See MiNTZER, supra note 150, at 27.

153. MINTZER, supra note 150, at 28-29.

154. Id.

155. See Mansnerus, supra note 19 , at A1.

156. See supra note 148-49 and accompanying text.

157. Cf. MiNTZER, supra note 150 , at 28 .

158. Indeed, adoption agencies have no incentive to disclose statistics regarding failed adoptions to prospective adoptive parents or the public in general, as widespread knowledge of the information would likely make the agency's services appear less attractive.

159. See Scherreik, supra note 7, at 134E4 ("Experts estimate that $25 \%$ to $50 \%$ of potential placements fall through."); see also Gearino, supra note 7 (citing a survey of readers of Adoptive Families magazine finding that twenty-nine percent of readers polled had a domestic adoption fail at some point before one succeeded).

160. See Mansnerus, supra note 19, at A1; see also Steven Pressman, The Baby Brokers, CAL. LAW., July 1991, at 30, 34, 105.

161. Donnelly, supra note 56, § 6:20. See generally People ex rel. Anonymous v. Anonymous, 195 N.Y.S.2d 1009 (Sup. Ct. 1959) (explaining that the birth mother refused to carry out the adoption plan after receiving funds from the adoptive parents for months prior to the birth). 
A birth parent's change of heart is doubtless an emotionally devastating event for prospective adoptive parents. Unfortunately, it may be financially devastating as well. The vast majority of expenses paid by prospective adoptive parents in connection with a domestic adoption - particularly birth-mother living expenses - are paid before the birth of the child. ${ }^{162}$ But a birth mother may not execute a surrender of parental rights or consent to an adoption until some period of time after the child is born. ${ }^{163}$ Thus, in almost all cases, when a birth mother changes her mind and decides to parent the child herself, the prospective adoptive parents, who now find themselves without the child they had hoped to parent, have already paid living expenses. ${ }^{164}$ Still worse, distraught adoptive parents almost always have no means of recovering the expenses they paid from either the adoption agency involved or the birth mother who has decided to parent. ${ }^{165}$ The financial risk of domestic adoption is simply too great for many qualified prospective adoptive families to bear, and, thus, they turn away from domestic adoption and toward other countries to build their families.

Perhaps an even graver concern than the potential loss of adoptive parents to intercountry adoption, however, is the very real possibility that the cost of domestic adoption may lead to the loss of many quality adoptive families altogether. In essence, the high cost of infant adoption

162. Many states require adoptive parents to report expenses paid to birth parents before the birth of the child. See, e.g., ARIZ. REV. STAT. ANN. § 8-114(B) (2007); CAL. FAM. CODE § 8610(a) (West 2004); Fla. Stat. AnN. § 63.132 (West 2005 \& Supp. 2010); IdAho Code ANN. § 16-1515 (West 2006); Мich. Comp. Laws ANN. § 710.54(7) (West 2002); Mo. AnN. STAT. § 453.075(1) (West 2003); N.H. Rev. Stat. AnN. § 170-B:13 (Supp. 2009); N.M. Stat. AnN. § 32A-5-34(A) (West 2003 \& Supp. 2009); OKLA. STAT. ANN. tit. 10, § 7505-3.2(A) (West 2009); S.C. CODE ANN. § 639-740 (2010); TENN. CODE ANN. § 36-1-116(b)(16)(A)-(C) (West 2009); UTAH CODE ANN. § 78B-6140 (West 2009 \& Supp. 2010); VT. STAT. ANN. tit. 15A, § 3-702 (West 2007).

163. See, e.g., KAN. STAT. ANN. §59-2116 (2005) (consent or relinquishment may not be given or accepted until twelve hours after the birth of a child).

164. See Pressman, supra note 160 , at $34,105$.

165. See, e.g., MinN. STAT. ANN. § 259.55(2) (West 2007) (“A contract purporting to require a birth parent to reimburse a prospective adoptive parent for [living expenses] under any circumstances ... is void as against public policy.”); MO. ANN. STAT. § 453.075 (allowing a court to decline to issue the decree of adoption if it finds that any payments were unreasonable or prohibited by statute); MONT. CODE ANN. § 42-7-105(4) (2009) ("It is illegal to require repayment or reimbursement of anything provided to a birth parent."); N.H. REV. STAT. ANN. § 170-B:13(II) (“A contract purporting to require a natural parent to reimburse a prospective adoptive parent for payments [permitted by $\S 170-\mathrm{B}: 13(\mathrm{I})$ ] under any circumstances ... is void as against public policy.”); Wis. STAT. ANN. § 48.837(6)(b) (West 2008 \& Supp. 2009) (“Upon a finding that payments which are impermissible ... have been made, the court may dismiss the petition...."); see also Hollinger, supra note 27, at 49. 
in the United States may price many families out of the market for a child. ${ }^{166}$

\section{Paid Today, Gone Tomorrow}

The bulk of the financial uncertainty surrounding living-expense payments made in connection with domestic adoption flows from the notion that they are paid in advance of the birth and generally not returned to the prospective adoptive parents under any circumstances. State law supports the payment of birth-mother living expenses and provides prospective adoptive parents no means of recovering the monies they pay regardless of whether the birth mother ultimately places her child for adoption.

If a birth mother perpetrates a fraud on a prospective adoptive family to reap financial reward-never intending to go through with the placement agreement she perfected or otherwise misrepresenting her status or intentions in a way that is designed to unjustly enrich her to the prospective adoptive parents' detriment-state laws permit the prospective adoptive parents to file suit against the birth mother for fraud. ${ }^{167}$ Where this cause of action can be proven, the defrauded prospective adoptive parents may recover damages for the loss they sustained, possibly including all sums paid to and on behalf of the birth mother and other damages, including those for emotional distress. ${ }^{168}$

166. See Klinke, supra note 26, at 148 (arguing that if the surrogate mother fee is too high, some caring couples will not be able to afford it).

167. See, e.g., CAL. PENAL CODE $\S 273$ (c) (West 2008) (creating a misdemeanor for any parent who obtains financial benefit with the intent to either not complete the adoption or not consent to the adoption); 720 ILl. COMP. STAT. ANN. 525/4.1(d-1) (West 2010) (allowing reimbursement where natural parent either knew that she was not pregnant or accepted payments from more than one adoptive family); IND. CODE ANN. § 35-46-1-9.5 (West 2004 \& Supp. 2010) (stating that birth mother commits "adoption deception" if she knowingly or intentionally benefits from expenses "when [she] knows or should have known that [she] is not pregnant," when the first adoptive parent is not aware that "another prospective adoptive parent is also paying adoption related expenses ... in an effort to adopt the same child," or when the mother does not intend to make an adoptive placement); Nev. Rev. StAT. ANN. § 127.287(2) (West 2008) ("It is unlawful for any person to receive payment for medical and other necessary expenses related to the birth of a child from a prospective adoptive parent with the intent of not consenting to or completing the adoption of the child."); N.C. GEN. STAT. ANN. § 48-10-03(d) (West 2000) (“A prospective adoptive parent may seek to recover a payment if the parent or other person receives or accepts it with the fraudulent intent to prevent the proposed adoption from being completed.").

168. See Burr v. Bd. of Cnty. Comm'rs of Stark Cnty., 491 N.E.2d 1101, 1108 (Ohio 1986). See generally Steven J. Gaynor, Annotation, Fraud Actions: Right to Recovery for Mental or Emotional Distress, 11 A.L.R. 5th 88 (1993) ("[I]n an action for fraud, damages for emotional distress may be recovered if the defendant should have been aware that his conduct involved an unreasonable risk of causing emotional distress ...."). 
In one particularly well-publicized case, Maya-Anne Mays worked with an adoption agency to be matched with prospective adoptive parents who might provide a loving home for the child she claimed to be carrying - a child whose father she said was a soldier killed in Iraq. ${ }^{169}$ Ms. Mays took money from three couples who desired to adopt her baby $-\$ 250$ from one couple for unspecified expenses, $\$ 1050$ from another couple for rent, and nearly $\$ 12,000$ for two months from a third couple. ${ }^{170}$ None of those families succeeded in adopting Mays's baby. In fact, it is unclear whether she ever had a baby at all. Mays's attorney contended at trial that she delivered a baby stillborn and dropped it outside an Oregon hospital. ${ }^{171}$ Oregon officials did not believe her story; they prosecuted Mays for hatching a scheme to defraud area couples by faking pregnancy to induce payments of substantial living expenses. ${ }^{172}$ After Mays's lawyer failed to present any evidence substantiating her pregnancy at trial, ${ }^{173}$ Mays was convicted and sentenced to a three-year prison term. ${ }^{174}$ Whether the couples who provided Mays with monies for living expenses ever recovered the funds of which they were deprived is unclear, but each of these couples could likely have pursued a civil suit against Mays. ${ }^{175}$ Cases like that involving Maya-Anne Mays ${ }^{176}$ are certainly troubling, but, in the end, prospective adoptive parents are wellprotected by state laws on fraud. ${ }^{177}$

The real difficulty in this area is in establishing fraud in connection with the adoption plan a birth mother makes for her child. ${ }^{178}$ Making out

169. Calif. Woman on Trial for Adoption Scam, MSNBC (Sept. 16, 2004), http://www.msnbc. msn.com/id/6022964.

170. Demian Bulwa, Woman Convicted of Adoption Fraud Insists She's Pregnant Now, S.F. Chron., Oct. 25, 2007, at B1. To the extent these payments were for Ms. Mays's pregnancy-related living expenses, they were permissible expenditures under Oregon law. OR. REV. STAT. ANN. $\S 109.311(1)$ (West 2003 \& Supp. 2010).

171. Calif. Woman on Trial for Adoption Scam, supra note 169.

172. Id. That a person could profit from one of these schemes at all shows rather handily that allowable payments in connection with domestic adoption are not merely those directly related to the birth but are essentially cash payments akin to those which would be paid for purchase of a commodity.

173. Id.

174. Bulwa, supra note 170 , at B1.

175. See Riley Hill Gen. Contractor, Inc. v. Tandy Corp., 737 P.2d 595, 605 (Or. 1987) (stating the elements of fraud under Oregon law).

176. See Mills, supra note 21 (describing a more recent but strikingly similar story).

177. Of course, there are significant limitations to pursuing a fraud claim against birth mothers, who are typically poor and likely judgment proof. See Kelly, supra note 135, at 17 (stating that birth mothers are often "poor, illiterate, and young").

178. See John R. Maley, Note, Wrongful Adoption: Monetary Damages as a Superior Remedy to Annulment for Adoptive Parents Victimized by Adoption Fraud, 20 IND. L. REV. 709, 709 (1987) 
such a claim requires proof of fraudulent intent. ${ }^{179}$ And while that intent may be proved by circumstantial evidence, ${ }^{180}$ it is rather difficult to come by. Unless the alleged birth mother is not pregnant at all when she develops an adoption plan and accepts payments of living and other expenses from prospective adoptive parents, she is likely to have second thoughts and, in fact, to vacillate frequently in her decision-making regarding her unborn child. ${ }^{181}$ Indeed, most mental health professionals agree that while a birth mother may perfect an adoption plan and fully intend to stick with it and place her child as the plan describes, the decision must be made all over again once the child is born. ${ }^{182}$ Under the circumstances that necessarily surround domestic adoptions, then, one would expect to see evidence of vacillation, doubt, and uncertainty surrounding a birth parent's decision to relinquish a child for adoption. As a result, any circumstantial evidence of fraud should be viewed skeptically, and proof of fraudulent intent ought to be more strongly demonstrated in the adoption context than it must be in the typical fraud case. Proof issues aside, most pregnant women perfecting an adoption plan are not acting with intent to defraud prospective adoptive parents in making the plan; they simply want the best for their babies and believe they are moving toward a positive future both for themselves and the children to whom they will give birth. ${ }^{183}$ That these women may later change their minds and choose to parent does not mean they ever possessed a fraudulent intent. In short, only in the very rare domestic adoption case is fraud committed. Cases like that involving Maya-Anne Mays do arise, but, thankfully, they occur rather infrequently.

In the garden-variety domestic-adoption failure, then, there is no fraud, but simply a change of heart. And in these cases, would-be adoptive parents almost always find themselves with no child and no

(describing the difficulties faced by adoptive parents in recovering when birth parents act fraudulently).

179. 37 AM. JUR. 2D Fraud and Deceit $\S 23$ (2001).

180. Id. § 496.

181. See Carol Sanger, Separating from Children, 96 Colum. L. REv. 375, 443 (1996).

182. See Susan Ayres, Kairos and Safe Havens: The Timing and Calamity of Unwanted Birth, 15 WM. \& MARY J. WOMEN \& L. 227, 279 (2009) (noting that early decisions to make an adoption plan are often made, but until the point of delivery, there is typically no real emotional commitment to those decisions); see also HOLLINGER ET AL., supra note 83, § 2.11[1][a] (stating that "the hormonal and other physiological changes that occur... may render the biological mother unusually susceptible to external pressures to retain her child").

183. See Ayres, supra note 182, at 279-80 (discussing difficulty of the birth parent's decision to relinquish); Hearings, supra note 3, at 17 (testimony of William Acosta, Deputy Comm'r, Div. of Servs., N.Y. State Dep't of Soc. Servs.) (testifying that birth mothers are often told that if they change their minds and choose to parent, they will be depriving "the child of a lifestyle that [they] could not hope to provide"). 
means of recouping the often substantial sums of money they have already expended, particularly when it comes to housing payments made on behalf of the birth mother during pregnancy. Adoption agencies are generally well-insulated from the claims of disappointed prospective adoptive parents, ${ }^{184}$ largely because agency-drafted contracts expressly state that all fees paid to the agency in connection with an adoption are nonrefundable under any and all circumstances. ${ }^{185}$ Moreover, many expenses paid by prospective adoptive parents are paid directly to thirdparty service providers. ${ }^{186}$ Housing may well be one such expense. ${ }^{187}$ In fact, it may be more logical in some cases for prospective adoptive parents to arrange to make, for instance, rental payments on behalf of a birth mother directly to the landlord, to ensure that only actual expenses are covered. In these cases, the agency has no role in the payment of sums directly from the prospective adoptive parents to a third-party housing provider, and the agency cannot be called upon to refund living expenses paid if the adoption fails. ${ }^{188}$ Likewise, the third-party housing provider owes no duty to prospective adoptive parents with whom he has no contractual relationship; he has provided the service for which he was paid. ${ }^{189}$

If anyone owes a duty of reimbursement to prospective adoptive parents, it is the birth mother who received cost-free housing and chose not to complete her adoption plan. The decision regarding the fate of the child is the birth mother's to make, ${ }^{190}$ and almost no one would argue that she lacks the right to make whatever final decision she wishes. ${ }^{191}$ But if the birth mother chooses to parent the child, she has essentially received a huge financial benefit from prospective adoptive parents to

184. See Kurt Mundorff, Note, Children as Chattel: Invoking the Thirteenth Amendment to Reform Child Welfare, 1 CARDOZO PUB. L. POL'Y \& ETHICS J. 131, 133 (2003).

185. See, e.g., Agency Policies, AdOPTION AssociATES, InC., http://www.adoptassoc.com/about/ agency_policies/ (last visited Oct. 7, 2010).

186. Many states require prospective adoptive parents to report such payments. See, e.g., GA. CODE ANN. § 19-8-13(C) (West 2010); IowA CODE ANN. § 600.9(2) (West 2001 \& Supp. 2010); Minn. Stat. AnN. § 259.55 (West 2007); N.H. Rev. Stat. AnN. § 170-B:13(I) (Supp. 2009); N.D. CEnT. CODE § 14-15-10(1) (West 2008); OHIO REV. CODE ANN. § 3107.055(C) (West Supp. 2010); OKLA. Stat. AnN. tit. 10, § 7505-3.2(B) (West 2009); 23 PA. Cons. Stat. AnN. § 2533(d) (West 2001); see also Zierdt, supra note 1, at 34.

187. Iowa Code AnN. $§ 600.9(2)$; MinN. Stat. AnN. $§ 259.55(2)$, (4); N.H. Rev. Stat. AnN. $\S$ 170-B:13(I); N.D. CEnT. CodE § 14-15-10(1)(d)-(e); OHIO REv. Code AnN. § 3107.055(C); 23 PA. CONS. STAT. ANN. $§ 2533(d)$.

188. See 18 SAmuel Williston \& Richard A. LORD, A TREATiSE ON THE LAW OF CONTRACTS $\S 52: 38$ (4th ed. 2001).

189. See id.

190. 2 C.J.S. Adoption of Persons $\S 71$ (2003).

191. See People ex rel. Anonymous v. Anonymous, 195 N.Y.S.2d 1009, 1019 (Sup. Ct. 1959). 
whom she provided nothing but heartache in return. ${ }^{192}$ From a purely equitable standpoint, the end result of such a failed adoption should be to put the parties back into their original positions. ${ }^{193}$ This would require a birth mother who received housing payments under an adoption plan she did not fulfill to reimburse prospective adoptive parents in the amount of the benefit she received. Assuming no fraud exists, as is true in the vast majority of cases, a state law cause of action such as unjust enrichment could be used to pursue this recovery, and it may fit the bill quite well. ${ }^{194}$ The problem, simply stated, is that courts almost never charge a birth parent in a failed adoption with the duty to repay monies received from prospective adoptive parents who desired to adopt the child. ${ }^{195}$

Even for the lucky couple for whom a planned domestic adoption succeeds - with the birth parents executing surrenders in accordance with the adoption plan-prospective adoptive parents have a limited practical ability to have living expenses they paid in connection with the adoption reviewed in any meaningful way for reasonableness, necessity, or any other limiting standard. Most states do require prospective adoptive parents to disclose all fees paid in connection with an adoption when they petition the court for finalization of the adoption. ${ }^{196}$ And some state courts have ordered intermediary agencies to reimburse prospective adoptive parents for fees paid which were in excess of the state

192. Cf. Klinke, supra note 26, at 120-21; Pressman, supra note 160, at 34-105.

193. See, e.g., IDAHO CODE ANN. § 16-1515(2) (West 2006) (allowing prospective parents in failed adoptions to sue for expense reimbursement and damages).

194. See 26 WILLISTON \& LORD, supra note 188 , § 52:38.

195. See, e.g., A.L. v. P.A., 517 A.2d 494, 497-98 (N.J. Super. Ct. App. Div. 1986) (holding that adoptive parents cannot recover any out-of-pocket expenses spent on the adoptive child while in the adoptive parents' custody if the birth parents breach the "adoption contract" and regain control of the child).

196. See Ala. Code $\S 26-10 A-23(b)$ (2009); Alaska StAT. ANN. § 25.23.090(a) (West 2007); Ariz. Rev. StAT. AnN. § 8-114(E) (2007); ARK. CODE AnN. § 9-9-211(a) (West 2009); CAL. FAM. CODE $\$ 8610$ (West 2004); Fla. Stat. ANN. § 63.132 (West 2005 \& Supp. 2010); GA. CodE AnN. $\S$ 19-8-13(c) (West 2010); IdAHo Code AnN. § 18-1511 (2006); 720 Ill. Comp. Stat. AnN. 525/4.1(e) (West 2010); IOWA CODE ANN. § 600.9(2) (West 2001 \& Supp. 2010); KAN. STAT. ANN. $\S 59-2121$ (b) (2005); Ky. ReV. StAT. AnN. § 199.590(6) (West 2006); LA. Child. Code AnN. art. 1200(A) (2004); Me. ReV. Stat. AnN. tit. 18-A, § 9-306(b) (1998); Mich. Comp. Laws AnN. $\S$ 710.54(7) (West 2002); Mo. AnN. Stat. § 453.075(1) (West 2003); Nev. Rev. Stat. AnN. $\S 127.127$ (West 2008); N.H. REV. Stat. AnN. § 170-B:19(V) (Supp. 2009); N.J. STAT. AnN. § 9:355 (West 2002 \& Supp. 2010); N.Y. DOM. REL. LAW § 115(8) (McKinney 1999); N.C. GEN. STAT. AnN. § 48-2-602 (West 2000); N.D. Cent. Code ANN. § 14-15-10(1) (West 2008); OKLA. Stat. AnN. tit. 10, § 7505-3.2(A) (West 2009); OR. ReV. Stat. AnN. § 109.311(1) (West 2003 \& Supp. 2010); 23 PA. Cons. Stat. ANN. $§ 2531$ (West 2001 \& Supp. 2010); S.C. CodE ANN. § 63-9-740 (2010); TENN. CODE ANN. § 36-1-116(b)(16) (West 2009); UTAH CODE ANN. § 78B-6-140 (West 2009 \& Supp. 2010); VT. Stat. AnN. tit. 15A, § 3-702 (West 2007); W. VA. CodE AnN. § 48-22803(f) (West 2002); WIS. STAT. ANN. § 48.913(6) (West 2008 \& Supp. 2009). 
standard. ${ }^{197}$ But those cases are exceptionally rare. Courts almost never order expense reimbursement in a successful adoption at the finalization stage. ${ }^{198}$ The focus of the proceeding at that point simply rests elsewhere. Moreover, as previously discussed, many states find such reimbursement orders a violation of public policy. ${ }^{199}$ And, of course, birth mothers placing their children for adoption are typically poor women against whom any judgment is likely virtually uncollectible. ${ }^{200}$

As a result, whether they are successful in adopting the children delivered by the birth mothers with whom they are matched or not, prospective adoptive parents are highly unlikely to see the return of any monies they expend for birth-parent living expenses. And if their first attempt at adoption results in failure, which is statistically quite likely, many prospective adoptive parents do not have the financial means to start the adoption process anew after losing tens of thousands of dollars. In the current legal landscape, a failed adoption will likely mark the end of a prospective adoptive parent's journey.

\section{A Skewed Pool of Prospective Adoptive Parents Along Lines of Wealth}

That domestic adoption is too expensive is a relatively noncontroversial assertion. Considering the hundreds of thousands of children available for adoption each year, serious attempts need to be made to balance the free-market approach under which only the wealthiest of couples will become parents through domestic adoption. Reducing the expense for families pursuing domestic adoption would better serve the needs of our children.

197. See In re Baby Girl D., 517 A.2d 925 (Pa. 1986); see also OHio ReV. Code ANN. $\S 3107.055$ (D) (West $2005 \&$ Supp. 2008) (allowing the court to order the amount reduced or require reimbursement if it finds an amount on the accounting unreasonable); OKLA. STAT. ANN. tit. 10, $\S 7505-3.2(\mathrm{~A}) .2$ (allowing the court to order reimbursement if some fees or charges are unlawful or unreasonable); VT. STAT. ANN. tit. 15A, § 3-703(a)(8) (requiring that before issuing the final decree of adoption, the court must conduct an accounting and must deny, modify, or order "reimbursement of any payment or disbursement that is not authorized ... or is unreasonable or unnecessary when compared with the expenses customarily incurred in connection with an adoption").

198. See End Baby Commerce, supra note 103, at 7 ("[T] he state exercises very little oversight in determining what is 'reasonable."'); Escobar, supra note 127, at C6 (“[J]ust how carefully expenses are scrutinized [by state district judges] is an open question.").

199. See, e.g., 720 Ill. Comp. Stat. AnN. 525/4.1(d); Мich. Comp. LaWs AnN. § 710.54(6); MinN. Stat. ANN. § 259.55 (West 2007); Mont. Code ANN. § 42-7-105(4) (2009); N.H. Rev. STAT. AnN. § 170-B:13(II); N.J. Stat. ANN. § 9:3-39.1(e) (West 2002 \& Supp. 2010); N.C. Gen. STAt. ANN. § 48-10-103(c).

200. Kelly, supra note 135 , at 17. 
Living expenses of the birth parents are only one of the many expenses that arise in connection with domestic adoption. ${ }^{201}$ If any real effort were made to reform American adoption procedure to make it more palatable from a cost perspective, agency and attorney brokerage fees, as significant costs of a domestic adoption, ${ }^{202}$ would need to be reviewed as well. Nonetheless, birth-parent living expenses often make up a large portion of a domestic adoption budget. ${ }^{203}$ The permissibility of these payments contributes to the small size of the pool of prospective adoptive parents who can afford domestic adoption.

Some may argue that prospective adoptive parents who are unable to afford birth-mother living expenses are too poor to adopt anyway, and thus, perhaps it is in the best interest of children that such parents are priced out of the adoption market. ${ }^{204}$ This argument fails to consider, however, that the average income of a family in this country is around $\$ 61,000 .^{205}$ Reasonable birth-mother living expenses of $\$ 1500$ per month for a period of six months, or a total of $\$ 9000$, represents nearly fifteen percent of a typical family's annual income and may be very difficult for prospective adoptive parents to front at the start of an adoption. Such difficulties do not mean that these same prospective adoptive parents would be unable to adequately raise the child they

201. Lucas, supra note 21 , at $555-56$.

202. See Pressman, supra note 160, at 33 (stating that, in 1991, an independent baby broker would offer to represent each prospective adoptive couple for a fee of $\$ 3000$, but the baby broker did not guarantee that the birth mother would choose the couple; the baby broker may have sent out twenty offer letters to introduce prospective adoptive couples to the same pregnant woman, and if the baby broker got five replies with fee payment, he made $\$ 15,000$ and didn't help any of them). For a current example of agency fees in a domestic adoption, see Sliding Scale: Affording Adoption, PREMIER ADOPTION, http://www.premieradoption.org/adoptive-parents/affording-adoption/slidingscale (last visited Oct. 7, 2010) (listing agency fees as ranging from $\$ 13,500$ to $\$ 21,500$, depending on adoptive family income).

203. See generally Lucas, supra note 21, at 555-56; Gearino, supra note 7.

204. See Richard B. Wirthlin, American Public Attitudes Toward Infant Adoption, in ADOPTION FАСТВOOK IV, supra note 2, at 223, 225 (surveying fifty states and showing that the American public thinks single mothers seeking to adopt with an average annual income of $\$ 50,000$ to $\$ 74,900$ will be "good mothers" at a much higher percentage rate than those earning $\$ 35,000$ or less per year); NAT'L COMM'N ON CHILDREN, BEYOND RHETORIC: A NeW AMERICAN AGENDA FOR CHILDREN AND FAMILIES 64 (1991) (“[F]or children to develop fully, their fundamental needs must be met: care and attention from loving parents and caregivers, an adequate family income, good nutrition and basic health care, a quality education, adequate housing, and a safe neighborhood."). But see D.C. CODE § 4-1410 (2008) ("inability of adoptive applicants to pay for all or any part of [costs associated with placing a child] shall not be a disqualifying factor in determining whether applicants are suitable parents for the child.").

205. Carmen DeNavas-Walt et al., U.S. Census Bureau, Income, Poverty, and Health INSURANCE COVERAGE IN THE UNITED STATES: 2009, at 5 (2010) (reporting the average family household income for 2009). 
adopt. The cost of raising a child is borne slowly over time, ${ }^{206}$ and there are cost efficiencies and economies of scale inherent in adding to an existing family that do not exist when it comes to advancing a nonhousehold-member's expenses for many months. ${ }^{207}$ Moreover, "[m]any homes with scarce financial resources are nevertheless adequate to provide the love, protection and support that children require."208

With the American foster-care system in crisis, ${ }^{209}$ one must also consider whether it is a positive development that some families wishing to adopt cannot afford to build families through domestic infant adoption; the hope is that such families will turn to the foster-care system and adopt from there at little or no cost. ${ }^{210}$ Unfortunately, the current foster-care system is not an attractive alternative for many prospective adoptive parents, regardless of their financial inability to pursue a private or agency adoption. The rather scant possibility that a fostered child will have a case plan orientated toward eventual adoption, ${ }^{211}$ the likelihood that the child will suffer long-term effects of abuse and neglect, ${ }^{212}$ and the relative infrequency with which very young children are available for adoption $^{213}$ makes the fost-adopt system an unacceptable alternative for many families.

In short, the risk of allowing birth-parent living expenses to be paid in connection with a domestic infant adoption means that birth parents

\section{Id. at 9 .}

207. $I d$.

208. In re Baby Girl D., 517 A.2d 925, 927 (Pa. 1986); cf. Hearings, supra note 3, at 4 (statement of Hon. Robert K. Dornan, Rep. of Cal.) (finding that adoptive couples are not rich but will endure financial sacrifices for the child and are often so desperate that they will pay any price for the chance to raise a child).

209. See Pew Comm'n on Children in Foster Care, Fostering the Future: Safety, Permanence and Well-Being for Children in Foster Care, in ADOPTION FACTBOOK IV, supra note 2, at 279.

210. Adopting a child out of the U.S. foster care system through a public agency will often come at no cost to the adoptive family. Adoption Financing Information: How to Cover the Costs, NATIONAL ADOPTION CENTER, http://www.adopt.org/assembled/financing_more.html (last visited Oct. 7, 2010). Indeed, fost-adopt parents may receive assistance from the state for the children they take into their care. $I d$.

211. See Thomas C. Atwood et al., Judicial Leadership to Ensure Sound Permanency Decisions for Children in Foster Care: Practical Guidelines for Juvenile and Family Courts, in ADOPTION FACTBOOK IV, supra note 2, at 289, 291 (stating that only twenty percent of all children in the foster-care system have case goals of permanent adoption).

212. Pew Comm'n on Children in Foster Care, supra note 209, at 280 ("Children who spend many years in multiple foster homes are substantially more likely than other children to face emotional, behavioral, and academic challenges. As adults, they are more likely to experience homelessness, unemployment, and other problems.").

213. Cf. Atwood et al., supra note 211, at 295 (stating that it can take up to twelve months from the date the foster child is removed from his or her home before the first permanent placement hearing is held but noting that twelve months "should be the upper limit"). 
are likely to select adoptive parents who can pay these expenses over those who cannot. Indeed, substantial evidence exists to demonstrate that birth mothers regularly engage in just this type of selective behavior - when they live in states that do not allow prospective adoptive parents to pay birth-mother housing benefits, they flock to states more friendly in allowing these payments to give birth and place their children. ${ }^{214}$ Thus, state law sanctioning payment of living expenses may discourage all but the wealthiest of families from pursuing the domestic adoption of an infant, thereby diminishing the pool of prospective adoptive parents and inhibiting the ability of loving and capable families to be candidates as adoptive parents through domestic adoption. And while "financial considerations are certainly a factor, placement of children in adoptive homes should not rest solely on the wealth of the adoptors." ${ }^{215}$ Such a result is clearly not in the best interest of the 22,000 or so children relinquished in infant domestic adoptions each year. ${ }^{216}$

\section{The Misplacement of the Support Burden}

One of the most troubling features of state law allowing the prospective adoptive parents of a child to pay birth-mother living expenses is that these rules place the burden of caring for a birth mother in necessitous circumstances on the shoulders of a party who, from a logical standpoint, should not bear it. One scholar has warned, for instance, that if adoptive parents are not legally free to provide birth mothers with reasonable financial support during pregnancy, the likely result will be an "epidemic of teen-age mothers necessarily on welfare." $" 17$ Aside from the fact that there is no reason to believe the prediction has any merit, ${ }^{218}$ shouldn't the government bear more of the

214. In Adoption House, Inc. v. P.M., No. 02-12-07TN, 00-37796, 2003 WL 23354141, at*3-4 (Del. Fam. Ct. Oct. 9, 2003), a birth mother refused to agree to adoption in Pennsylvania because, at that time, Pennsylvania law did not permit the payment of birth-mother living expenses. She decided instead on a couple from New York, a state in which living expenses were allowed. Id. at *3. Two years later, when the same birth mother sought an adopting couple for another child, she decided first on a couple from Louisiana, who later changed their minds at the hospital after learning the child was biracial. $I d$. at $* 3-4$. The birth mother finally decided on a Delaware couple, as Delaware state law permitted the payment of living expenses. Id. at *5; see also Zierdt, supra note 1 , at 31-32.

215. In re Baby Girl D., 517 A.2d 925, 927 (Pa. 1986).

216. See Sally Kalson, International Adoptions by Americans Get Really Tough, PITTSBURGH Post-GAZETTE, Mar. 15, 2009, at A1 (noting that American children in need of adoption are disadvantaged when more prospective adoptive parents look abroad).

217. Rea, supra note 112, at 145.

218. Indeed, the percentage of persons on welfare in states such as Alaska and Kentucky, whose 
responsibility for taking care of its citizens than should a prospective adoptive parent who hopes for, but has no guarantee whatsoever of, the chance to parent a birth mother's child? The question of the propriety of the existence of social welfare programs in general is highly controversial, but as long as such programs exist and their purpose is to protect the interests of the nation and state's most needy citizens, birth mothers and their unborn fetuses seem to fall squarely within the domain of those eligible for government assistance. In short, states have an interest in protecting their birth-mother citizens. Prospective adoptive parents have no such duty. But the very existence of state laws that allow prospective adoptive parents to legally cover birth-mother living expenses means that, for all practical purposes, it is adoptive parents who bear the burden of birth-mother care that the state or federal government would likely otherwise bear. ${ }^{219}$

In the Medicaid context, an evaluation of the proper placement of the burden of caring for needy birth mothers and their fetuses has been made. When pregnant women considering adoption for their unborn children live in poverty, their medical expenses in connection with the pregnancy are typically covered by Medicaid. ${ }^{220}$ In the case of In re Adoption of Baby Boy M., at finalization of the adoption proceeding, the Kansas trial court ordered the adoptive parents to reimburse Medicaid for expenses covered by that program for the birth mother's medical expenses in delivering the child. ${ }^{21}$ The appellate court reversed, holding that no law required the adoptive parents to make this reimbursement, and in the absence of any such provision, the adoptive parents held no such duty. ${ }^{222}$ Michigan allocates responsibility for a birth mother's medical expenses even more clearly; prospective adoptive parents are only permitted to pay medical expenses incurred by the birth mother in

liberal rules allow for the greatest payments of birth-mother living expenses, is higher than that in Colorado, a state which prohibits the payment of birth-mother living expenses altogether. See State Per Capita Welfare Caseloads, STATEMASTER.CoM, http://www.statemaster.com/graph/eco_wel_ cas_tot_fam_percap-caseloads-total-families-per-capita (last visited Nov. 14, 2010).

219. The placement of the support burden on prospective adoptive parents, typically strangers to the birth mother and not predisposed to bestow upon her any gratuity, leads to the nearly inescapable conclusion that the payments made are really made for the child itself.

220. States that elect to cover the medically needy under their Medicaid plans are required to cover children under age eighteen and pregnant women under federal guidelines. See Mandatory Eligibility Groups Medicaid Eligibility, U.S. DEP'T OF HEALTH AND HUMAN SERvS., http://www.cms.hhs.gov/MedicaidEligibility/03_MandatoryEligibilityGroups.asp (last visited Oct. 7, 2010).

221. 18 P.3d 304, 304-05 (Kan. Ct. App. 2001).

222. Id. 
connection with an adoption if those expenses are not covered by Medicaid. ${ }^{223}$

In essence, even in a successful adoption, states generally place the burden of caring for the medical needs of the birth mother during pregnancy on the government, rather than on adoptive parents. To do otherwise in the context of living expenses - where the possibilities may include government assistance with housing through a program of social welfare or private coverage of birth mother living expenses by prospective adoptive parents-is inconsistent with the rules governing Medicaid and difficult to justify.

When the birth mother is married at the time of the adoptive placement-which is not all that rare - even more significant questions arise concerning the placement of the burden of paying her living expenses on the prospective adoptive parents' shoulders. The only rational reason for allowing the birth mother to receive monies on which to live from the prospective adoptive parents - and to allow her to, at the same time, avoid a serious charge of baby selling - is that these monies pay for the birth mother to live during a period for which she is unable to work, typically only a lengthy period if there are complications in the pregnancy. The pregnancy of the birth mother should not interfere with her husband's ability to work, however. And in every state, spouses have a duty to support each other financially during marriage, a duty which is taken quite seriously and enforced with some regularity even while marriages are ongoing. ${ }^{24}$ Thus, a married birth mother is already owed a primary duty of support by her husband. Allowing prospective adoptive parents to pay her living expenses without caveat shifts the primary obligation for the birth mother's support from her spouse to typically unrelated adoptive parents. Essentially, they allow the husband of a birth mother to profit from the adoptive parents while simultaneously abdicating his own responsibility for her support.

223. Мich. COMP. LAWS ANN. § 710.54(3)(b) (West 2002).

224. See, e.g., CAL. FAM. CODE $\S 720$ (West 2004) ("Husband and wife contract toward each other obligations of mutual respect, fidelity, and support.”); CONN. GEN. STAT. ANN. § 46b-37 (West 2009) ("[i]t shall be the joint duty of each spouse to support his or her family."); DEL. CODE ANN. tit. $13, \S 502$ (West 2006) ("[The] duty to support a spouse rests upon the other spouse."); LA. CIV. CODE ANN. art. 98 (1999) ("Married persons owe each other fidelity, support, and assistance."); MONT. CODE ANN. § 40-2-102 (West 2009). 


\section{Prohibition: The OnLy Adoption-SAVING Alternative}

Domestic adoption is facing a serious crisis. The success rate of planned placements is abysmal. Adoptive parents are defecting to intercountry adoption in masses. And the requirement that prospective adoptive parents pay exorbitant fees to adopt makes domestic adoption impossible for many couples. Indeed, the President of the National Council for Adoption, an agency advocacy group, recently remarked that "you don't need a lesson in economics" to understand that the adoption marketplace has created perverse consequences, particularly related to race. $^{225}$ Indeed, something akin to a price schedule has emerged for white babies, distinct from that applicable to racial minorities. ${ }^{226}$

The American system of private and agency adoption needs to be reformed dramatically. A modest, yet transformative place to start in reregulating the baby market ${ }^{227}$ is with a ban on prospective adoptive parents' payment of birth-family living expenses.

Time has demonstrated that less conservative reform will be ineffective at solving the problems plaguing domestic adoption. Reasonableness and necessity limitations have not succeeded, nor have small dollar caps on living expenses. "Because less than [two] percent of unmarried pregnant women are placing their babies for adoption, they now have "the option to be very, very selective." 228 Indeed, they have profited - not merely subsisted - from the existing domestic adoption landscape. Banning the payment of living expenses in connection with adoption would send a strong message distinguishing adoption from baby selling ${ }^{229}$ and increase the likelihood that more prospective adoptive parents would foray into domestic adoption, serving not only those adoptive parents but also children in need of homes. ${ }^{230}$

225. Mansnerus, supra note 19 , at A16.

226. Id.

227. Michele Goodwin, The Free-Market Approach to Adoption: The Value of a Baby, 26 B.C. THIRD WORLD L.J. 61, 61 (2006) (describing the current American adoption model as "resembl[ing] an unregulated marketplace in children").

228. Mansnerus, supra note 19, at A16.

229. See generally Andrea B. Carroll, Incentivizing Divorce, 30 CARDOZO L. REV. 1925, 196773 (2009) (describing the expressive function of rules in the family-law arena).

230. There is a risk that eliminating the living-expense windfall would lead more pregnant women to select abortion. See STEPHEN COLEMAN, THE ETHICS OF ARTIFICIAL UTERUSES: IMPLICATIONS FOR REPRODUCTION AND ABORTION 74 (2004) (describing sociological influences on the decision between adoption and abortion). This risk may be quite real, but it is unquantifiable. And fear of it is no longer a sufficient reason to continue a system demonstrated over time to be seriously flawed. 
The black market for babies was gutted nearly fifty years ago by the creation of relatively uniform state laws prohibiting baby selling. With domestic adoption currently facing serious challenges, the time has come to eliminate the gray-market activities - specifically the payment of birth-family living expenses - as well. 